\title{
Relatos, memórias e narrativas na construção do imaginário do povo Kaingang: as estampas de Joaquim José de Miranda na conquista dos Campos de Guarapuava
} Reports, memories and narratives in the construction of the
Kaingang's imaginary: Joaquim José de Miranda's prints
about the conquest of the Guarapuava fields

Toni Juliano Bandeira ${ }^{1}$

DOI: http://dx.doi.org/10.20435/tellus.v17i33.429

\begin{abstract}
Resumo: Nesta pesquisa, analisamos a representação imagética do povo Kaingang no conjunto de trinta e sete estampas produzidas por Joaquim José de Miranda sobre a décima das expedições destinadas a desbravar os chamados "sertões" do Tibagi, no estado do Paraná, expedição esta comandada por Afonso Botelho, no ano de 1771. Nesse sentido, refletimos sobre as formas de resistência indígena ante a invasão de seu território, bem como sobre a ideia do "vazio demográfico", na qual a existência de grupos indígenas no atual estado do Paraná simplesmente é negada, reproduzindo-se o discurso de que essas terras eram desabitadas, até que os luso-brasileiros ou imigrantes de outros países viessem cultivá-las. Por meio da análise das estampas, podemos dizer que a narrativa imagética de Miranda é um material de grande valor para a história do povo Kaingang, por meio do qual é possível refletir sobre o embate entre os colonizadores e os indígenas nos Campos de Guarapuava, notando-se a inconsistência da tese do "vazio demográfico", bem como a resistência Kaingang à invasão de seu território.
\end{abstract}

Palavras-chave: narrativa imagética; povo Kaingang; Joaquim José de Miranda.

Abstract: In this research we analyze the representation of the native tribe Kaingang presented in a series of 39 illustrations produced by Joaquin José de Miranda about the tenth expedition destined to brave the so called "sertões" of the area of Tibagi in the Paraná State. This expedition was commanded by Alfonso Botelho in the year of 1771. In this sense, we reflect about the ways of the natives' resistance in front of the invasion of their territory and in the same way we reflect also about the idea of the "demographic emptiness" by which the idea of the existence of groups of natives in the territory of the nowadays State of Paraná is just denied and there is just the reproduction of de discourse that this land was uninhabited until the Portuguese-Brazilian or immigrants from others countries could come and cultivate them. By the analysis of the illustrations we

\footnotetext{
${ }^{1}$ Secretaria de Estado da Educação do Paraná, Terra Indígena Rio das Cobras, Paraná, Brasil.
} 
can say that Miranda's imagetic narratives a material of great value to the history of the Kaingang people once through it is possible to reflect about the chocks between the colonizers and the Kaingang people in the fields of Guarapuava. These illustrations also show up the inconsistence of the thesis of a "geographical emptiness" as well as they reveal the resistance movement of the Kaingang against the invasion of their territory.

Key words: illustrative narrative; Kaingang tribe; Joaquim José de Miranda.

\section{A IMAGEM COMO REPRESENTAÇÃO: CONSTRUÇÃO DE IMAGINÁRIOS}

[...] As imagens não são nem um reflexo da realidade social nem um sistema de signos sem relação com a realidade social, mas ocupam uma variedade de posições entre estes extremos. Elas são testemunhas dos estereótipos, mas também das mudanças graduais, pelas quais indivíduos ou grupos vêm o mundo social, incluindo o mundo de sua imaginação. (BURKE, 2004, p. 232).

A utilização da imagem como fonte de conhecimento e reflexão sobre uma determinada época ou cultura já foi muito questionada devido a sua "confiabilidade", ou seja, refletia-se até que ponto e em que medida imagens poderiam servir para a compreensão de aspectos do objeto abordado. Para Burke (2004), existe um conflito permanente entre os que chama de "positivistas" e os céticos ou estruturalistas. Os primeiros acreditam que as imagens veiculam informações confiáveis sobre o mundo exterior, tentando perscrutar através da imagem para ver a realidade além dela. Os últimos "focalizam a atenção na imagem e somente nela, na sua organização interna, nas relações entre suas partes e entre uma imagem e outras do mesmo gênero". (BURKE, 2004, p. 232). Esse dilema é tamanho, que Burke (2004) diz que o considera, às vezes, um "diálogo de surdos", ou para usar uma criação mais visual, utiliza a chamada imagem "pato-coelho", escrevendo que "o desenho tão bem pode ser visto como um coelho ou como um pato, mas não ao mesmo tempo" (BURKE, 2004, p. 232-3).

O citado autor, a partir dessas considerações, acredita que há uma "terceira via" para ser trilhada por aqueles que assim desejarem. Os adeptos de tal perspectiva, em vez de descrever imagens como confiáveis ou não confiáveis, estão preocupados com "graus ou formas de confiabilidade e com confiabilidade para propósitos diferentes" (BURKE, 2004, p. 233). Desse modo, rejeita-se a simples oposição entre a visão da imagem como "espelho" ou "fotografia 
instantânea" da realidade, da mesma maneira, refuta-se a noção da imagem como nada mais do que um sistema de signos ou convenções. Os seguidores dessa "terceira via" alegam que, no caso das imagens - ou mesmo do texto -, "as convenções filtram informações sobre o mundo exterior mas não excluem" (BURKE, 2004, p. 233).

Nessa linha de pensamento, Burke (2004) cita o seguinte exemplo: lendo-se algo de um viajante ocidental ou de um historiador do século XIX, ou ao se observar o trabalho de um pintor do mesmo período, nós podemos muito bem estar conscientes das convenções individuais ou coletivas pelas quais os três representam uma cultura alienígena, como o império chinês. No entanto isso não impede que muitos detalhes sobre aquele império sejam transmitidos a nós, bem como informações sobre atitudes, valores e preconceitos do século XIX (BURKE, 2004, p. 233). Portanto

[...] os testemunhos sobre o passado oferecidos pelas imagens são de valor real, suplementado, bem como apoiando, as evidências dos documentos escritos. [As imagens] oferecem acesso a aspectos do passado que outras fontes não alcançam. (BURKE, 2004, p. 234).

Essa "terceira via" de análise proposta por Burke é a que julgamos ser a mais adequada para a interpretação das estampas de Miranda sobre os Kaingang dos Campos de Guarapuava. As imagens não são a "verdade", mas o seguinte fato é real: as tropas de Botelho se encontraram com os índios, e estes guerrearam para defender seu território dos invasores, como se comprova pelo próprio relatório de Afonso Botelho (SAMPAIO E SOUZA, 1956). Afirmar que as estampas foram feitas para reafirmar o discurso presente no relatório de Botelho parece muita obviedade, o contrário seria ridículo, visto que estas seriam anexadas ao texto escrito. Nesse sentido, os desenhos de Miranda, logicamente, resultam de uma espécie de filtro do autor, uma seleção de elementos suficientes para cumprir seus objetivos enquanto produtor. $O$ trabalho mais árduo consiste, a nosso ver, em relacionar as estampas, o relatório de Botelho e outras fontes escritas e visuais desse período histórico sobre os indígenas e suas relações com os nacionais, buscando-se entender de que maneira as referidas estampas contribuem para a memória do povo Kaingang. 


\section{AS EXPEDIÇÕES DE CONQUISTA DOS CAMPOS DE GUARAPUAVA: APONTAMENTOS HISTÓRICOS}

A relação que se buscava estabelecer com os indígenas que habitavam o que hoje corresponde ao território do estado do Paraná na segunda metade do século XVIII, era decorrente de um problema muito claro: a indefinição das fronteiras territoriais entre os domínios de Portugal e Espanha na fronteira sul do país. Note-se que, ainda em 1680, os portugueses haviam fundado a Colônia do Sacramento, defronte à cidade de Buenos Aires, uma tentativa de anexação de territórios no estuário do Prata que se consolidava como verdadeira afronta aos espanhóis. Estes não demoraram a erguer uma cidade adjacente à referida Colônia, atual Montevidéu, fundada em 1724. A disputa territorial deveria ser resolvida com a firmação do Tratado de Madri, no ano de 1750, segundo o qual "os espanhóis reconheciam os territórios ocidentais conquistados pelos portugueses para além dos limites do Tratado de Tordesilhas, em troca do abandono da Colônia do Sacramento e das pretensões lusas às terras ao norte do rio da Prata" (SEVCENKO, 2003, p. 20).

No entanto o Tratado de Madri foi revogado pelo de El Pardo (1761), refeito pelo Tratado de Santo Ildefonso que entregava a Colônia do Sacramento sem contrapartida dos Sete Povos (1777), e alterado pelo Tratado de Badajoz (1801) que dava, outra vez, os Sete Povos a Portugal. Desse modo, todas as expedições ao Tibagy e a Guarapuava nas décadas de 1760 e 1770 se dão neste "vácuo" criado pela revogação do Tratado de Madri.

Essa preocupação motivou algumas atitudes por parte de Sebastião José de Carvalho e Melo, o Marquês de Pombal, as quais refletiriam, também, na forma de relação que se buscaria estabelecer com os Kaingang que povoavam os Campos de Guarapuava. A garantia da posse desse território, para Pombal, teria de se firmar pela "ocupação populacional e colonização sistemática das áreas vulneráveis da colônia" (SEVCENKO, 2003, p. 20). Seriam os "soldados-colonos" os responsáveis por assegurar essas áreas ao domínio português. Nesse sentido:

Pombal sabia, porém, que não poderia contar com populações portuguesas, sob pena de despovoar e enfraquecer a Metrópole. Daí sua instrução enfática para que fossem 'abolidas todas as diferenças entre índios e portugueses', de modo que se pudesse contar com os próprios nativos como agentes colonizadores, atraindo ainda se possível os indígenas do lado espanhol, educando-os no português, adestrando-os e casando-os com europeus. (SEVCENKO, 2003, p. 21). 
Assim, Pombal esperava contar com os próprios indígenas para a efetiva ocupação e garantia de posse de vastos territórios fronteiriços. Nesse sentido, é interessante observar, por exemplo, que, na segunda metade do século XIX, o Barão do Rio Branco utilizou, com sucesso, como argumento crucial na questão de Palmas, exatamente as relações de portugueses com os Kaingang para defender que, onde havia Kaingang, as terras eram do Brasil.

Sem embargo, os encarregados de pôr em prática a política de Pombal nem sempre assim o faziam, como parece ter ocorrido com as expedições militares destinadas ao vale do Tibagi. Segundo Sevcenko (2003) D. Luís de Almeida, o Marquês de Lavradio, nomeado Vice-Rei do Brasil em 1769, denunciou, várias vezes, ao Marquês de Pombal, a forma de ação usurpadora dessas expedições, pois elas significavam a expropriação daquelas terras das comunidades indígenas locais, que eram suas legítimas possuidoras. Lavradio "temia que, atacados pelos paulistas, os indígenas ou se voltassem contra os portugueses de forma geral, com medo ou ressentimento, ou abandonassem a área, indo se refugiar no outro lado das fronteiras espanholas" (SEVCENKO, 2003, p. 22), justamente o que Pombal não desejava. Essas denúncias surtiram efeito, já que um despacho da Corte proibiu o envio de novas expedições até que se tivessem informações rigorosas sobre o comportamento dos expedicionários em relação aos indígenas.

Pouco se sabe sobre a vida de Joaquim José de Miranda, o autor das estampas. Segundo Belluzzo e Piccoli (2003), a transposição em narrativa visual de um relatório de uma expedição realizada pelo sertão não era prática usual na América portuguesa do século XVIII, sendo desconhecidas obras similares. As autoras ressaltam, ainda, que não se tem notícia da existência de nenhuma outra obra de Miranda. Nesse sentido, em um período de carência de representações iconográficas retratando o encontro entre índios e colonizadores no Brasil Colônia, as estampas de Miranda devem ser consideradas uma produção de grande valor artístico e histórico.

Como já relatamos, segundo Belluzzo e Piccoli (2003), a única informação que temos sobre a proveniência da obra de Miranda é um catálogo de leilão da Sotheby's, de Nova York, datado de 1985, no qual as estampas são dadas como "presumably lost for over 200 years", ou seja, os desenhos ficaram praticamente desconhecidos por cerca de dois séculos, daí o fato de não existirem muitos estudos sobre eles. Além disso, Stols (1996) comenta que, quando as estampas foram expostas em Bruxelas, no programa de Europália Portugal, a crítica deu, curiosamente, pouca atenção ao que foi, sem dúvida, uma verdadeira revelação de uma iconografia ignorada. "Houvesse- 
-se mostrado uma série de estampas chinesas desconhecidas, certamente o evento teria despertado numerosas apreciações dos especialistas" (STOLS, 1996, p. 22).

De acordo com o relatório de Botelho (1956), a décima expedição entrou pelo sítio do Carrapato no dia dezessete de novembro de 1771 e era formada por quase setenta pessoas, incluindo um capelão, o padre frei José de Santa Tereza. O primeiro encontro com os indígenas teria ocorrido no dia dezesseis de dezembro, sendo os Kaingang tratados "com todos os sinais de amor e desejos de conservar tratos de amizade até conseguir o fim de os reduzir ao grêmio da Igreja, verdadeiro projecto desta expedição" (SAMPAIO E SOUZA, 1956, p. 21). O comandante português relata, ainda, que, no começo do ano de 1772, em várias andanças pelos campos, os luso-brasileiros encontraram, muitas vezes, os indígenas, tratando-os, como sempre, "com muito agrado". No entanto, apesar do extremo cuidado com que o tenente-coronel Botelho deve ter escrito o relatório, neste momento, ele comete um deslize, pois, apesar de afirmar que sempre evitaram toda ocasião de ofender os indígenas, ele escreve que isso "não foi o bastante para deixar de vir" (SAMPAIO E SOUZA, 1956, p. 21). Fica claro, portanto, que, por algum motivo não citado, a expedição desagradou os Kaingang, o que aconteceu pouco antes do dia oito de janeiro, quando os indígenas mataram sete luso-brasileiros. O motivo exato da desavença jamais saberemos, mas é evidente que Botelho omitiu a narração de vários acontecimentos. Por que tiveram de "ofender" os indígenas? Que tipo de "ofensa" foi essa? Os escritos de Botelho não explicam nada sobre isso. Dito isso, talvez nem fosse necessário essa "ofensa", pois os Kaingang possivelmente guardavam na memória experiências passadas do contato com os não indígenas, existindo aqui, portanto, uma atualização da memória histórica.

\section{AS ESTAMPAS DE JOAQUIM JOSÉ DE MIRANDA NA CONQUISTA DOS CAMPOS DE GUARAPUAVA}

As estampas de Miranda, dentre outras interpretações, representam a resistência do povo Kaingang frente ao colonizador europeu. A produção desses desenhos é algo singular do que se sabe do contato nacional com o povo Kaingang, por isso consiste em material de grande valor, não apenas para sua história, como para o conhecimento de como foi se formando a atual conjuntura do estado do Paraná.

Introduzindo a sequência das trinta e sete estampas, são apresentadas seis figuras estáticas, as quais ocupam três estampas, recortadas e expostas sobre fundo 
aquarelado. Nessas figuras, aparecem homens e mulheres Kaingang com seus trajes e armas tradicionais, sendo que as mulheres são apresentadas, de um lado, com os trajes tradicionais, e de outro, com as vestimentas presenteadas pela expedição de Botelho. Veja-se a primeira estampa:

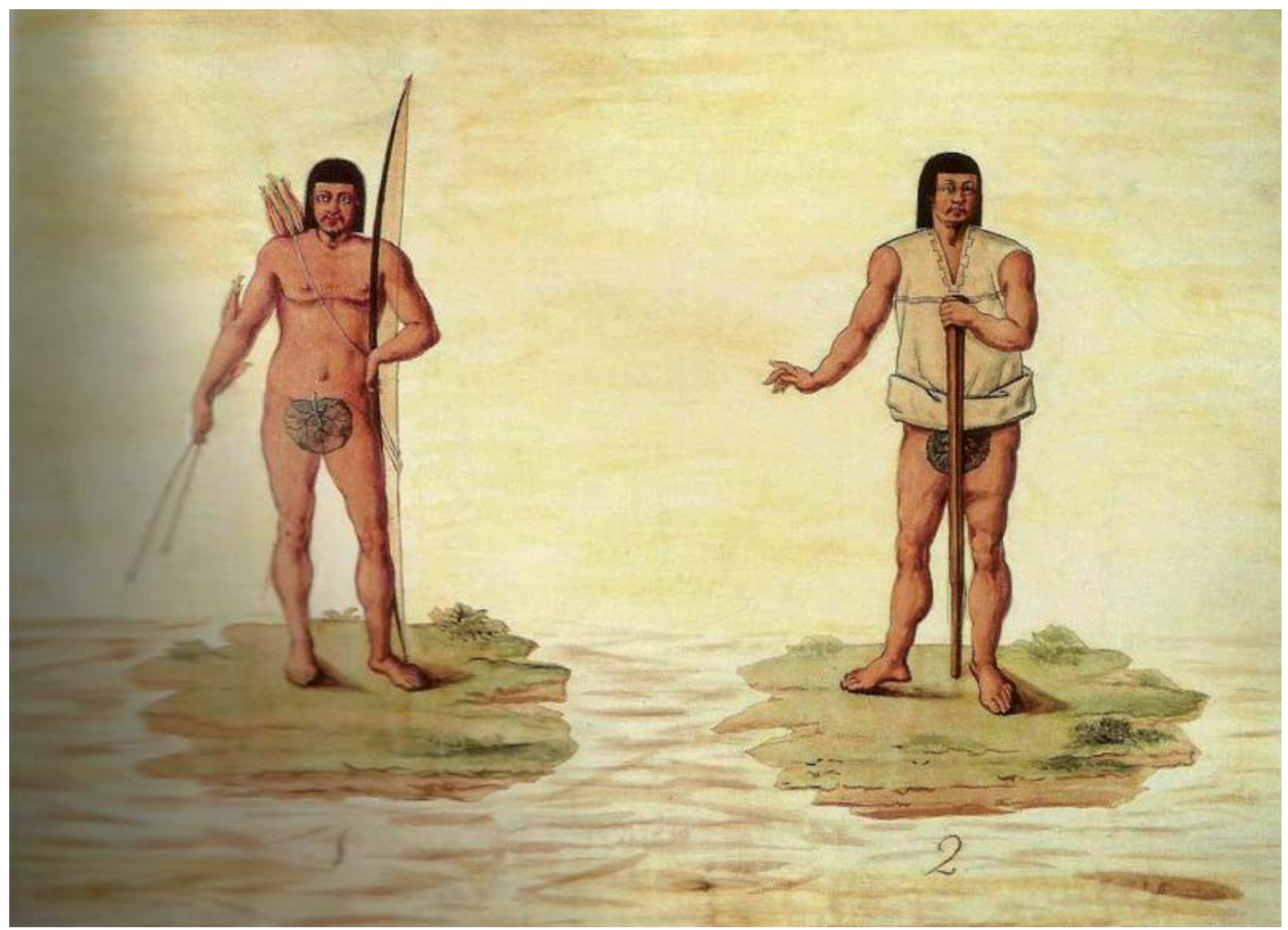

Figura 1- Cenas 1 e 2: o Indio de todo nu (mesmo sem a folha que se oferece á vista no meyo do corpo, que se pôs no pintado por decencia) com arco, e flexas, como reprezenta esta 1a figura / hum Indio com a camiza, e bordão, como se vê, e poucos aparecião com esta fraca roupa

Fonte: Sampaio e Souza $(1962)^{2}$.

Alguns elementos dessas imagens merecem ser destacados, pois são de interesse ao estudioso da cultura Kaingang. O arco e a flecha utilizados por eles em inúmeros combates com luso-brasileiros, espanhóis e outras tribos, foram descritos

\footnotetext{
${ }^{2}$ Optamos por reproduzir as legendas das estampas do modo que aparecem no relatório de Botelho (SAMPAIO E SOUZA, 1956), considerando que essas descrições são pertinentes para a compreensão das imagens. Assim, em todas as estampas apresentadas no texto, as legendas são do relatório de Botelho.
} 
por vários autores. Manizer (2006) , tratando dos Kaingang de São Paulo, entre os quais esteve de dezembro de 1914 a janeiro de 1915, dizia que os arcos Kaingang eram enormes, teria ele visto um com comprimento perto de três metros. "A madeira do arco é arredondada, se seccionado transversalmente. Ele não é nada recurvo, o que permite servir-se dele como se fosse uma borduna durante as brigas" (MANIZER, 2006, p. 31). Esta descrição é semelhante ao que se vê nas estampas de Miranda, arcos grandes, maiores que o homem Kaingang em pé, e poucos recurvados.

Borba (1908) dizia serem os Kaingang "bons atiradores, tanto com flechas como com espingardas; raramente erram o alvo que visam" (BORBA, 1908, p. 9). Na indústria do arco e flecha são abundantes os relatos que dão conta de uma habilidade admirável por parte dos índios, como comenta Mabilde (1983) acerca do que teria presenciado no ano de 1850, no "meio do sertão" do estado do Rio Grande do Sul:

Não obstante os poucos e toscos meios de que dispunham aqueles coroados para fazerem seus arcos, são contudo fabricados com igualdade, com uma uniformidade e perfeição de acabamento que seria difícil a um dos nossos melhores marceneiros - com toda a competente ferramenta à disposição - fabricar um melhor ou mais bem acabado. (MABILDE, 1983, p. 139).

O caráter belicoso dos Kaingang possibilitou retardarem por quase meio século a ocupação efetiva luso-brasileira dos Campos de Guarapuava. Franz Keller, em texto escrito em 1867, escreve:

Na mesma proporção que são tímidos e reservados o Guarani e Cayoá, apresenta-se o Coroado franco e até atrevido. É um povo eminentemente guerreiro, ao ponto de, não tendo com quem pelejar, procurar ao menos na caça a satisfazer o desejo de esperimentar as suas forças e astucia, e deve-se confessar que na caça da anta e do porco do mato chegarão a uma rara perfeição.

As armas d'elles, adequadas a esses exercicios são acabadas com um capricho extraordinario; os arcos compridos são de todo enlaçados com a casca do cipó Imbé, e as flechas, feitas com um páo de grande elasticidade, são trabalhadas de um modo que parecem torneadas. (KELLER, 1974, p. 15-6).

Com arcos, flechas e varapaus, os Kaingang defenderam, até a exaustão, suas terras tradicionais.

Em relação à nudez dos homens, coberta pela "decência" de Miranda com folhas verdes, a mesma é atestada por Borba (1908, p. 7): "Os homens andam nus, mas teem, quase todos, uns grandes mantos, curú-cuxa, feitos também com fibras de ortiga, com os quaes dançam em suas festas e cobrem-se nas noites frias". Kur 
é expressão pela qual os Kaingang, atualmente, designam todo tipo de roupa, kusa quer dizer "frio" "gelado". Em Rio das Cobras, muitos velhos Kaingang ainda recordam o modo como eram feitos esses mantos com fibras de urtiga, em Kaingang, pyrfé.

É interessante mencionar, sobre as vestimentas Kaingang, as anotações de Ambrosetti (1895, p. 318), quando relata que, por ocasião de seus "bailes", os índios "se ponen uma especie de camisetas muy estrechas, sin mangas, que llegan hasta la cadera". Os apontamentos desse autor descrevem, portanto, uma vestimenta exatamente igual à que Miranda desenhou. Deve-se mencionar, ainda, o bordão do Kaingang, os quais Botelho deduziu serem insígnias de oficiais. Esse bordão, na verdade, é o varapau, ou borduna, o mesmo que aparece em várias outras estampas de Miranda, como na cena 36, na qual um índio tenta acertar o cavalo do capitão Carneiro, ou mesmo o próprio capitão.

O primeiro encontro da expedição com os índios dos Campos de Guarapuava aconteceu no dia dezesseis de dezembro de 1771. Botelho assim relata:

Se avistou em um alto um grande rancho de gentio, onde chegando-se achou deserto de poucos dias, e nêle foram vistas várias alcôfas, e cestinhas e que êles têm guardados os seus pobres trastres, e entre êstes foi achada ũa simitrunfa, composta de penas não mal tecidas, e ũa fita trançada à maneira de liga, dous novelos de fio muito bem fiado, panelas, porongos, ou cabaços grandes, e um cheio de mel, carracaxazes, e outras cousas com que costumam fazer seus festejos; nas fontes circunvezinhas milho de môlho, e nos lagos pinhão, e outros víveres de que costumam sustentar-se; e por que se Ihe tiraram alguns dêstes trastes para mostrar-se, se recompensaram com outros, deixando-Ihe um barrete vermelho, duas facas, miçangas, medalhas, anéis, maravalhas, frocos, e outras cousas similhantes. (SAMPAIO E SOUZA, 1956, p. 29).

É interessante destacar, dessa citação, alguns elementos fundamentais da cultura material Kaingang, como as cestinhas, o mel, o milho e o pinhão de molho nas fontes e lagos, uma forma de conservá-los para deles se servirem posteriormente.

Esse primeiro encontro foi retratado por Joaquim José de Miranda em sete estampas, as de número seis a doze. A primeira ilustração dessa sequência narrativa é a que segue abaixo. 


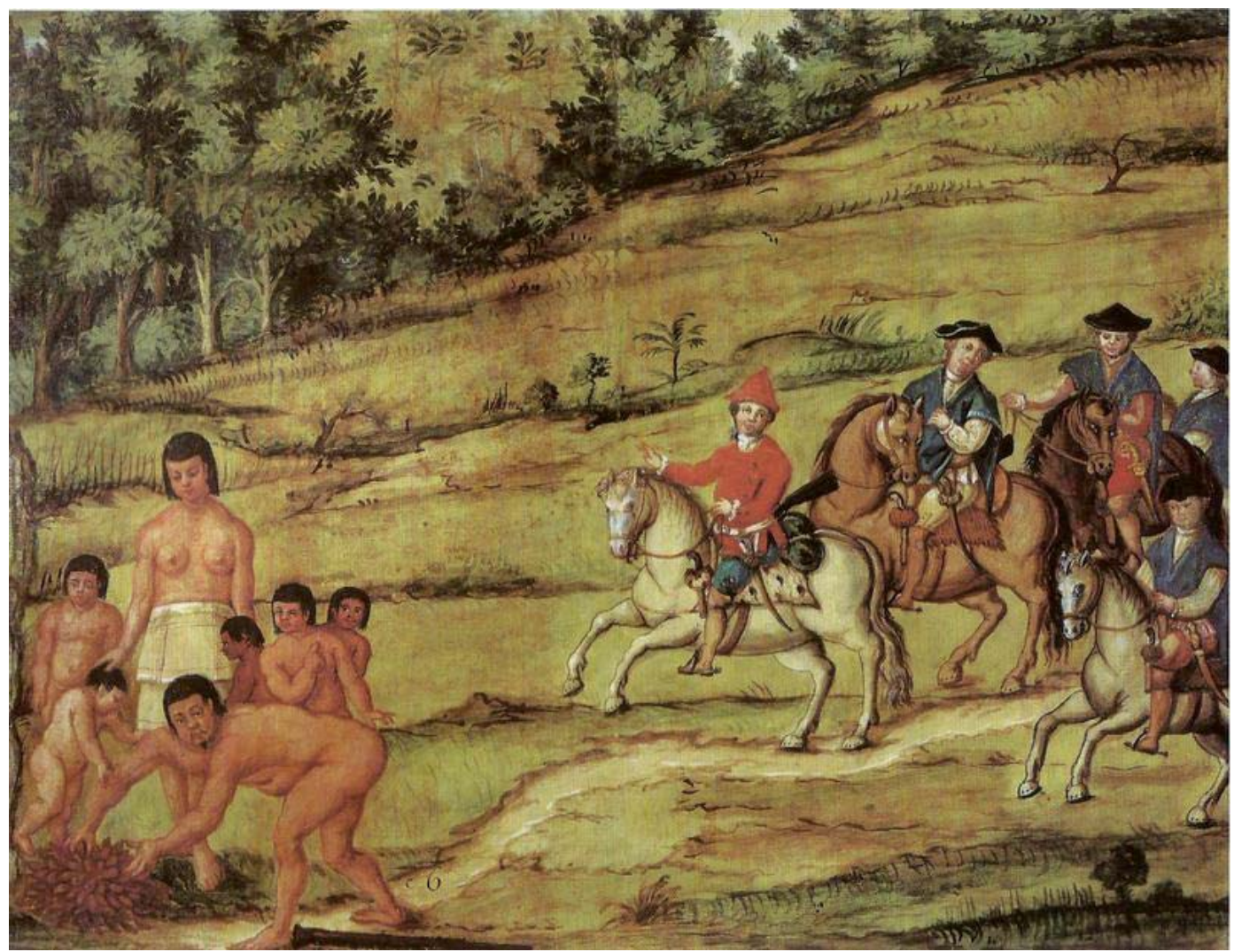

Figura 2 - Cena 6 - hum Indio com 5 filhos tirando pinhão do Lago, chega a vêlo o Tenente Cascaes com os 5 cavaleiros, que hião descobrir o campo Fonte: Sampaio e Souza (1962).

O pinhão figura em toda essa sequência do primeiro encontro do tenente Cascais com os indígenas. Cabe destacar que esse fruto é um alimento tradicional Kaingang, de modo que desenvolveram técnicas para conservar o pinhão. Uma das formas consistia em depositá-lo por alguns dias nos rios ou lagos, com o qual, depois de azedado, os índios faziam o ẽkór, um tipo de farinha do pinhão que podia ser armazenado por vários meses. A importância desse fruto na dieta alimentar Kaingang é registrada, por exemplo, por Ambrosetti (1895), quando o autor relata que os Kaingang da província de Misiones, na Argentina, depois de concluírem sua tarefa de pescar, voltavam à Serra Central, "donde los inmensos bosques de Araucarias (Araucaria brasiliensis) ó pinares, como allí los llaman, les brindaban sus frutos suculentos con los cuales se regalaban" (AMBROSETTI, 1895, p. 307). Ambrosetti 
(1895) registrou, também, uma das formas como os índios consumiam o pinhão, além do sabor desagradable ao paladar dos não indígenas que o teriam experimentado:

Con los piñones hacen una especie de pasta, que obtienen poniéndolos en el agua un cierto tiempo para que se hinchen y rompan su envoltorio, luego los colocan en el mortero, en donde los pisan; esta pasta la hacen hervir y luego la comen.

Los Indios dicen que son muy buenos, preparados así, y que tienen la ventaja, sobre los pinõnes crudos y asados directamente, de no hacer daño; pero los blancos que han probado este plato me aseguran que es muy desagradable, con un gusto ácido muy pronunciado. (AMBROSETTI, 1895, p. 327).

O próprio Botelho registra em seu relatório que, por ocasião da visita de alguns luso-brasileiros aos arranchamentos dos índios, estes Ihes ofereceram pinhão assado, anotando que os homens "comeram, e gostaram muito bem dêle dizendo, que era muito melhor que o outro, que haviam trazido do lago, com que ficaram os índios muito satisfeitos" (SAMPAIO E SOUZA, 1956, p. 35).

Nesse primeiro encontro, Botelho relata que, ao verem os militares, os indígenas:

[...] Arrebatadamente fugiram, e êles a rédea solta os alcançaram, exceto a mulher, que sempre entrou para o mato, fazendo-lhe logo ao longe sinais de paz batendo as palmas, com que parou o índio sobressaltado, e em extremo assustado, de que logo o tiraram o tenente um barrete de pisão vermelho em que duvidou pegar, mas lançando-Ihe de cima do cavalo o apanhou antes que chegasse à terra, ficando alegre, e muito mais quando o dito tenente despindo ũa chimarra de baeta côr-de-rosa lha deu, de que ficando muito contente pegou nela abraçando-a muito mais alegre; logo o mesmo tenente lha vestiu, de que mostrou ficar mais admirado, e contente. (SAMPAIO E SOUZA, 1956, p. 31).

Se os índios fugiram, assustados, é evidente que esse encontro não foi tranquilo, ao contrário do que se percebe nas estampas de Botelho. Os militares montavam cavalos que provavelmente impressionavam pela robustez, pois os animais utilizados pelos exploradores europeus na América, geralmente, eram das melhores raças e direcionados para a guerra. Sendo um animal desconhecido na América, o cavalo causava espanto e medo aos povos indígenas.

Na cena nove, os militares aparecem desfazendo-se de suas vestes para presenteá-las aos indígenas, uma cena que transparece uma relação bastante altruísta. Veja-se: 


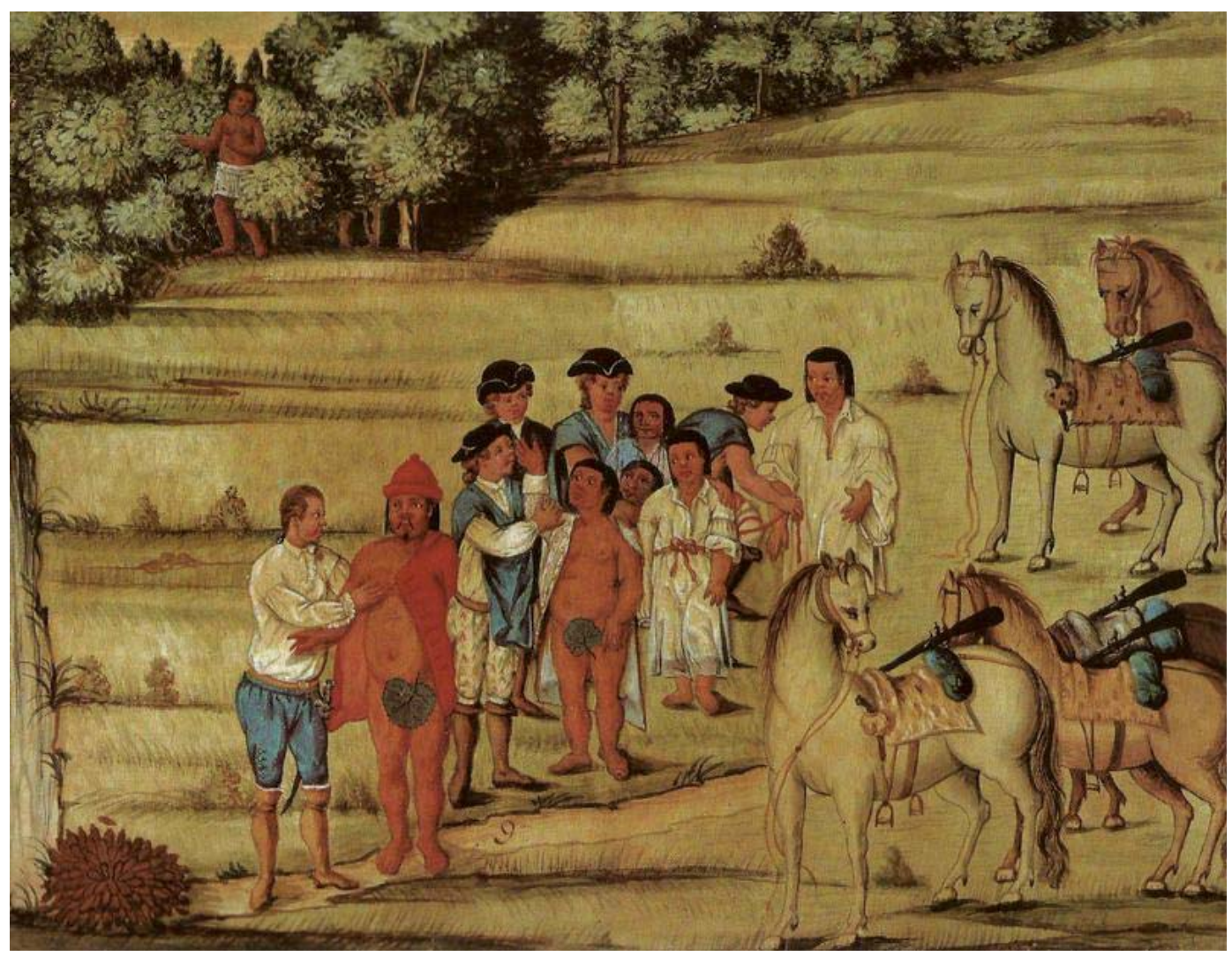

Figura 3- Cena 9 - despe o Tenente a chimarra vermelha, véstea ao Indio, e os mais Camaradas vestem os filhos, despindo-se dos seus proprios vestidos Fonte: Sampaio e Souza (1962).

Essa representação dos militares como caridosos e sensíveis à nudez do indígena repete-se na cena de número dez. Nesse primeiro módulo cênico, como em toda a série de estampas, é visível a superioridade das forças militares dos invasores paulistas, seja pelo armamento, que possuía até canhões, ou pela cavalaria. No entanto essa desproporcional superioridade é retratada nas estampas de Miranda como se jamais tivesse sido utilizada para tirar qualquer forma de proveito dos índios. Os militares, na representação imagética, tratam os Kaingang da melhor forma possível, agasalham os índios, abraçam-nos carinhosamente e distribuem mimos às crianças.

Nessa sequência de imagens que retrata o primeiro contato da tropa de Botelho com os indígenas, apenas a mulher não recebeu presentes, talvez porque, segundo Botelho, somente ela não pode ser alcançada pela corrida dos cavalos, pois que 
teria, sempre, se internado pela mata. Recortamos, da cena sete, a representação de Miranda sobre esse fato.

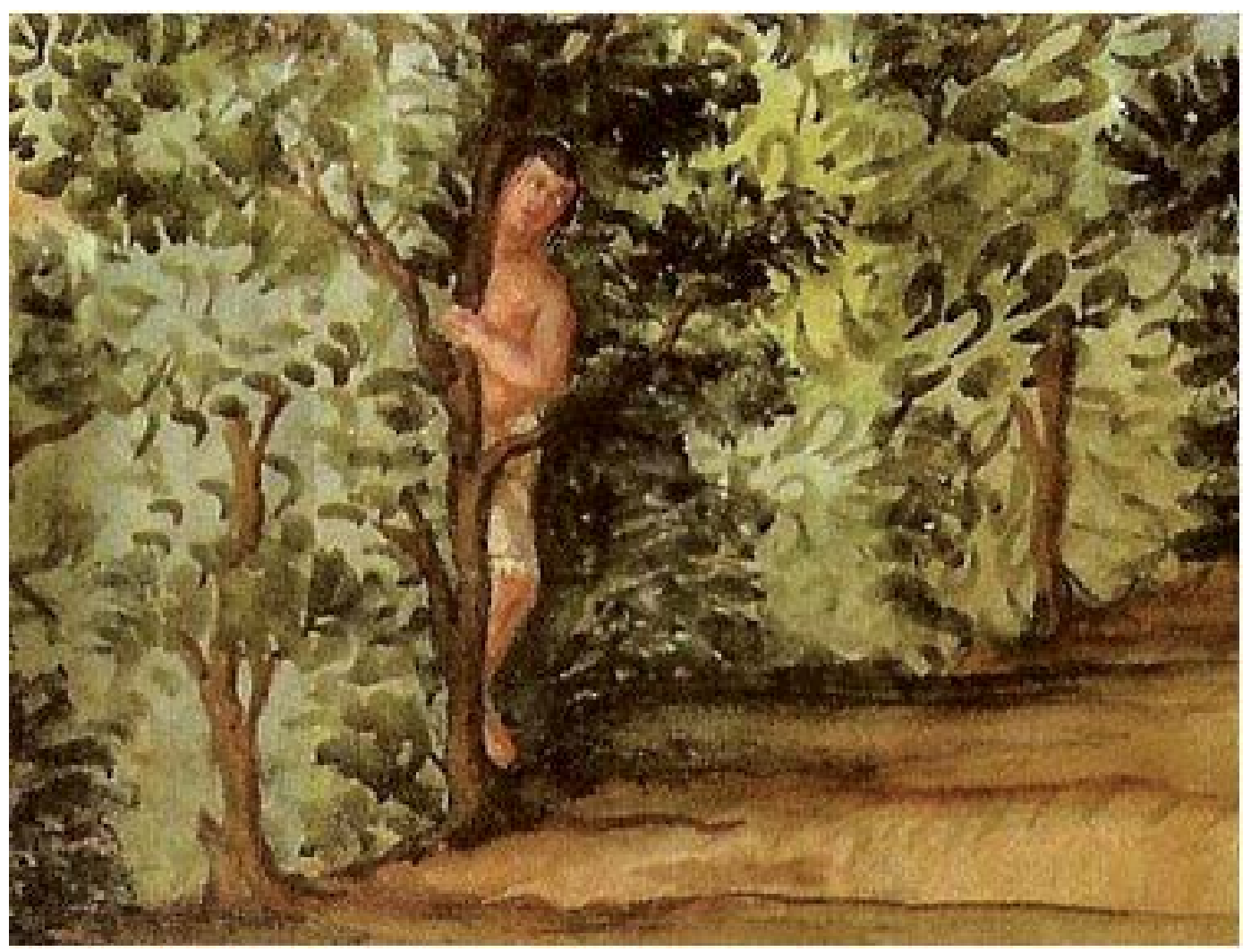

Figura 4- Detalhe da cena 7, a indígena que fugiu para a mata Fonte: Sampaio e Souza (1962).

Sendo assim, com todos esses afagos e desejos de paz com os indígenas, os homens de Botelho talvez esperassem ser bem recebidos nos Campos de Guarapuava, fundar povoações para incorporar definitivamente essa vasta região ao território nacional, isso por meio da ocupação efetiva e colonização das terras indígenas.

Por ser uma obra de grande singularidade, Sevcenko (2003) considera a produção de Miranda como um documento cultural prodigioso.

A característica da representação denota o estilo típico das ilustrações cartográficas, combinando imagens de uma eloqüência didática, com os personagens apresentados em perspectiva frontal e os contextos observados em vôo 
de pássaro, como os que se observam inseridos em miniatura nos mapas do período, destinados a revelar os elementos mais peculiares ou exóticos dos diferentes e mais remotos recantos do mundo [...] (SEVCENKO, 2003, p. 23).

Belluzzo e Piccoli (2003), tratando da construção narrativa de Miranda, apontam que, nesta, a identificação do lugar tem uma função primordial, o qual se assenta sobre o território indígena e deriva de uma organização espacial. "Faz lembrar a experiência do engenheiro militar, que primeiro prepara o sítio, para depois fortificar, que primeiro faz a planta, para depois erguer o edifício" (BELLUZZO; PICCOLI, 2003, p. 50).

Na estampa de número onze, os quatro militares já estão montados nos cavalos, prontos para o retorno ao acampamento, enquanto o tenente Cascais, por meio de acenos, mostra ao indígena o local onde estavam acampados os luso-brasileiros, o qual promete visitá-los.

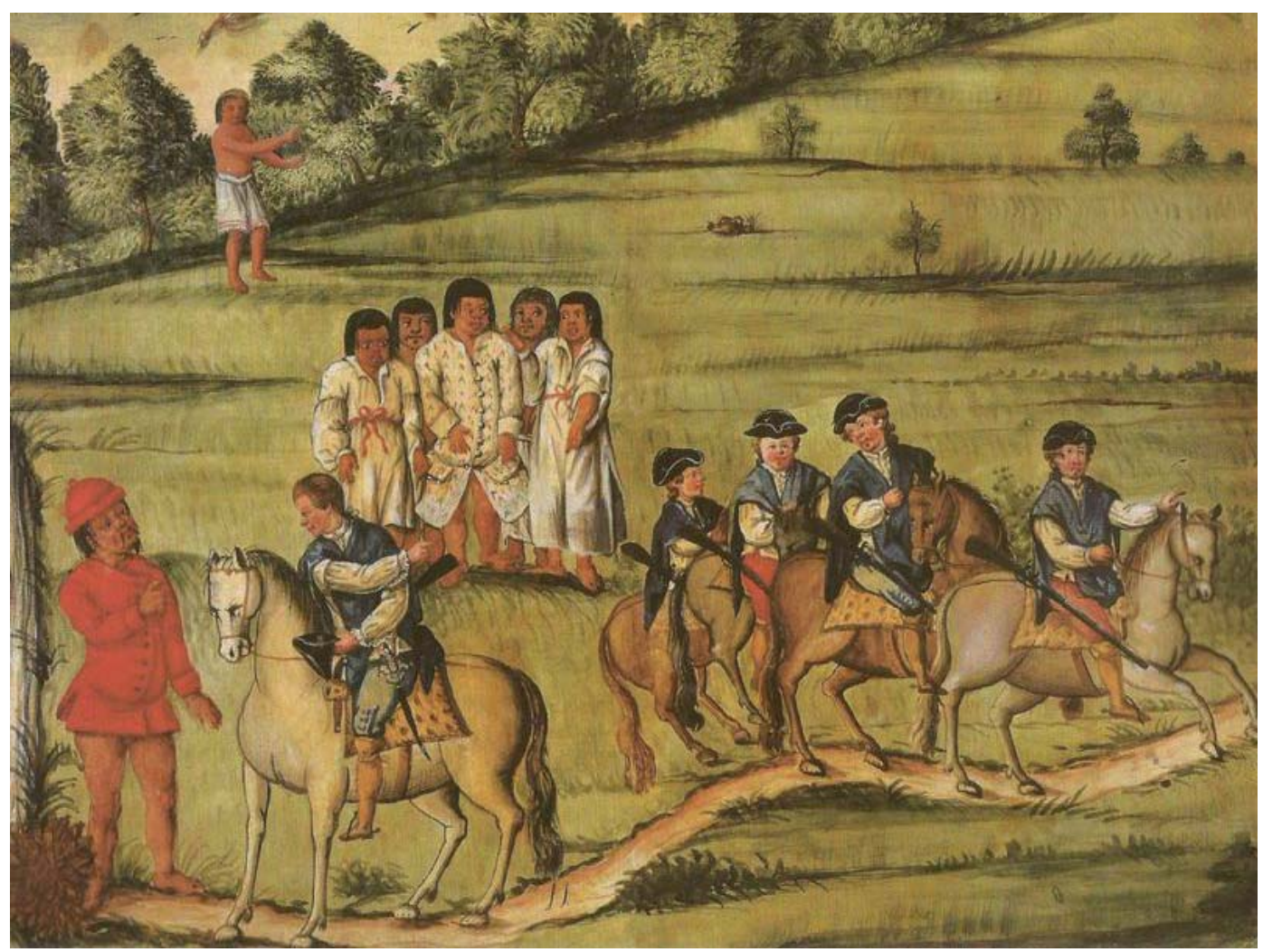

Figura 5 - Cena 11 - vestido os filhos, e o Indio seu Pay, a May vendo do mato, dá o Tenente hum facão ao Indio o qual o estima muito Fonte: Sampaio e Souza (1962). 
No dia seguinte, logo pela manhã, um grupo de oito indígenas apareceu no acampamento avançado dos militares, vinham guiados pelo homem que, no dia anterior, havia sido encontrado tirando pinhão em um lago, como representado na cena quinze.

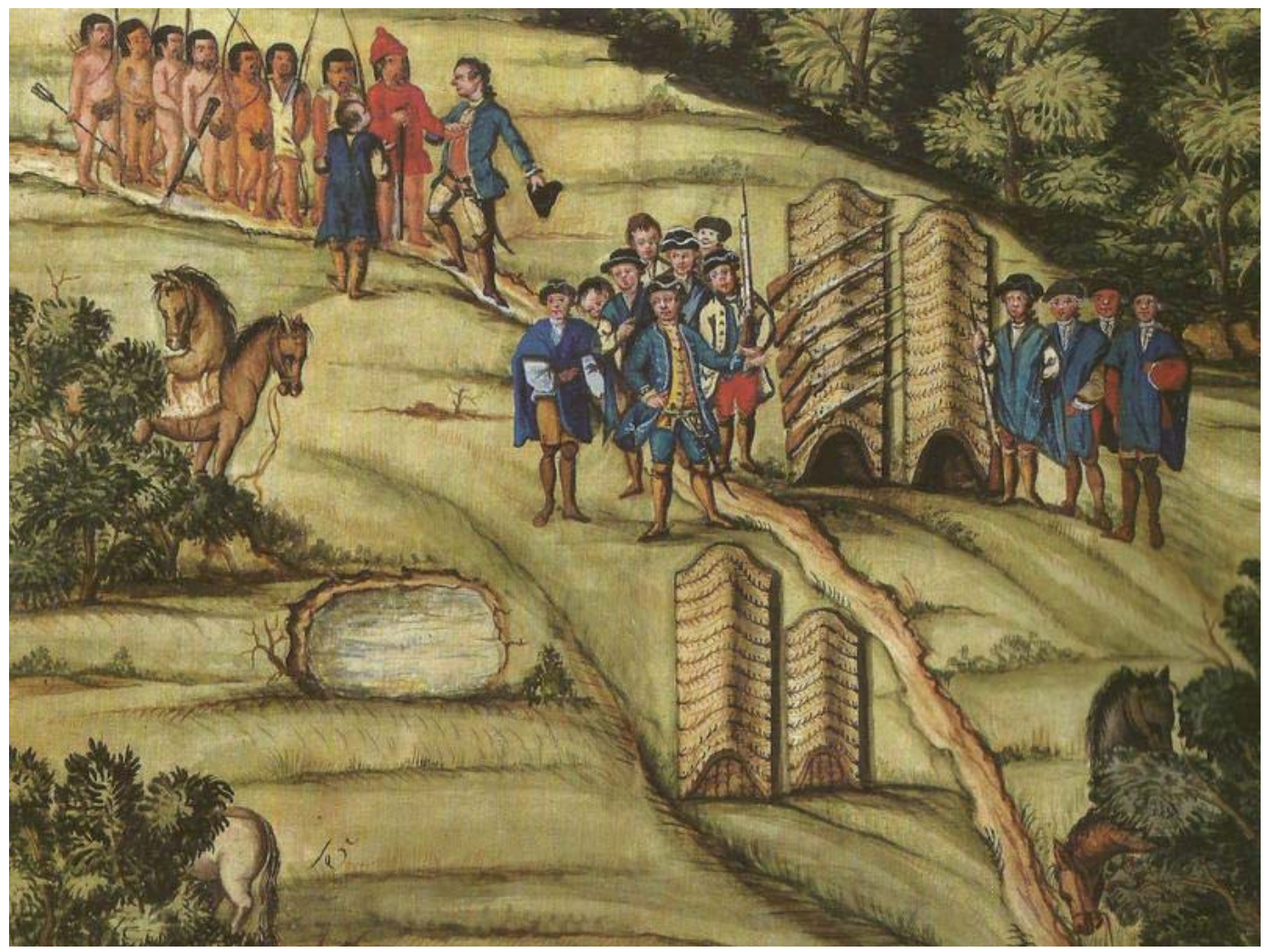

Figura 6- Cena 15 - chegando os Indios perto do arranchamento, muito receozos de chegar, mandou o Tenente Coronel recebelos por dois Camaradas dos que no dia antecedente os tinhão encontrado

Fonte: Sampaio e Souza (1962).

A visita dos indígenas ao arranchamento da expedição de Botelho constitui o segundo módulo cênico das estampas de Miranda, que vai das cenas de número catorze até a de número vinte e um. Botelho, mais uma vez, acentua em seu relatório que o tenente Cascais e João Lopes receberam os índios "abraçando-os e fazendo-Ihes muitas carícias, o que lhes coibiu algum receio com que vinham, e chegados os trataram muito alegres com grande carinho" (SAMPAIO E SOUZA, 1956, p. 32). Botelho assim descreve os indígenas: 
Dous traziam bordões na mão, de que se infiriu serem insígnias de oficiais entre êles, e os mais com arcos, e flechas, todos moços bem feitos, claros, e o mais velho teria cinqüenta anos, os cabelos cumpridos de um palmo pouco mais, ou menos, cortados por diante bem redondo, e dous com coroa no próprio lugar onde os nossos clérigos as têm, bem redondas, pouco maiores que as dos minoristas, as sobrancelhas rapadas todos em geral, as barbas crescidas, uns mais, e outros menos; e perguntando-Ihes por que as não rapavam, ou traziam como nós, responderam por acenos, que por não terem com quê: a fala tão bárbara, que é totalmente distincta da geral indiana. (SAMPAIO E SOUZA, 1956, p. 32).

A interessante anotação de Botelho de que dois dos índios possuíam uma "coroa", tal como algumas ordens de clérigos, foi também desenhada por Miranda em duas estampas, as cenas de números dezesseis e trinta e sete. Na primeira delas, Miranda retrata o tenente-coronel e outros homens recebendo os indígenas, abraçando-os e tratando-os bem. Recortamos parte desta cena para que se possa observar os apontamentos de Botelho.

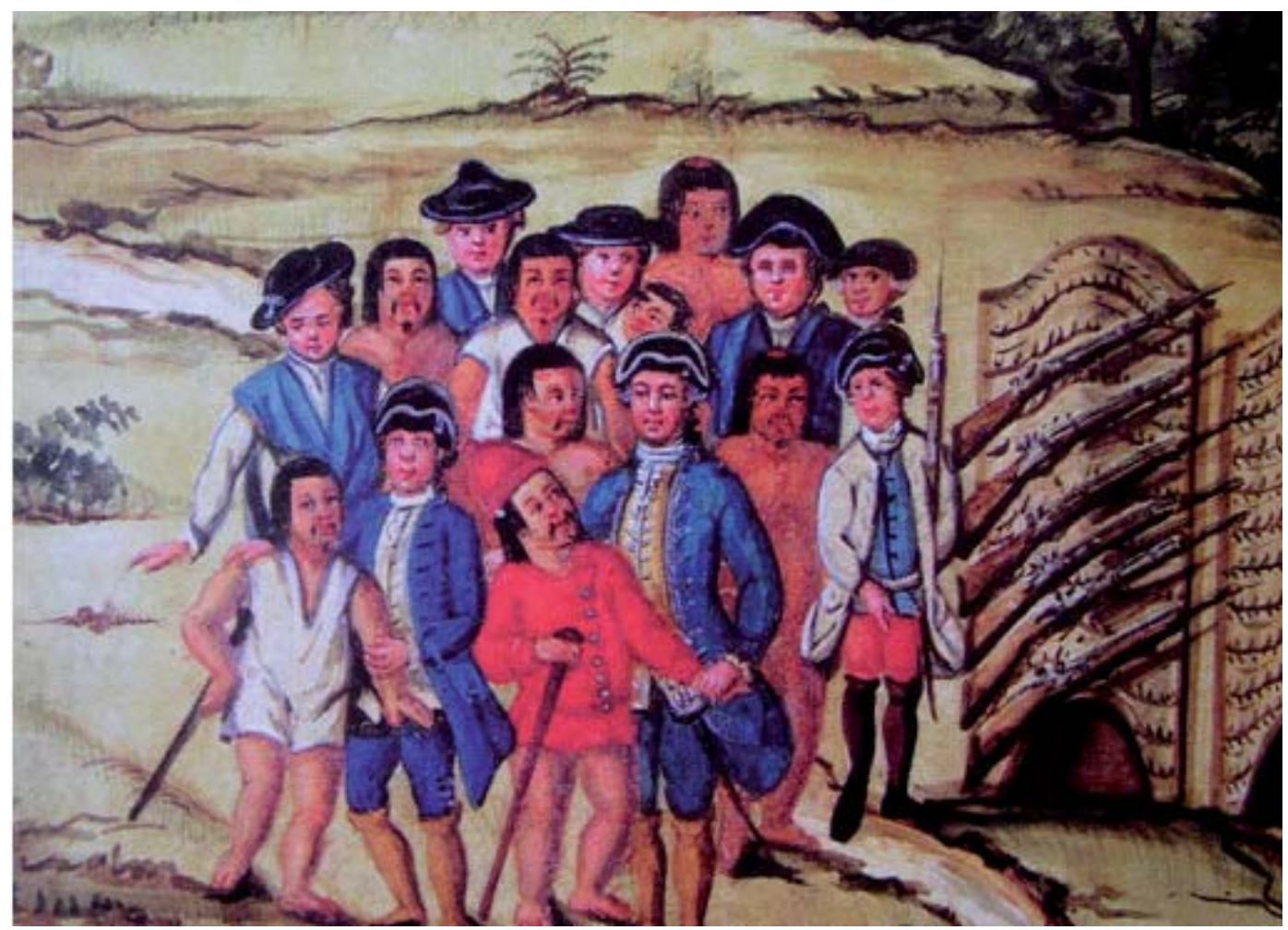

Figura 7 - Detalhe da cena 16, sobre a visita dos indígenas ao acampamento dos homens comandados por Botelho Fonte: Sampaio e Souza (1962). 
Na cena de número trinta e sete, também aparecem dois índios com "coroas", muito bem pintadas nas aquarelas de Miranda, como se vê:

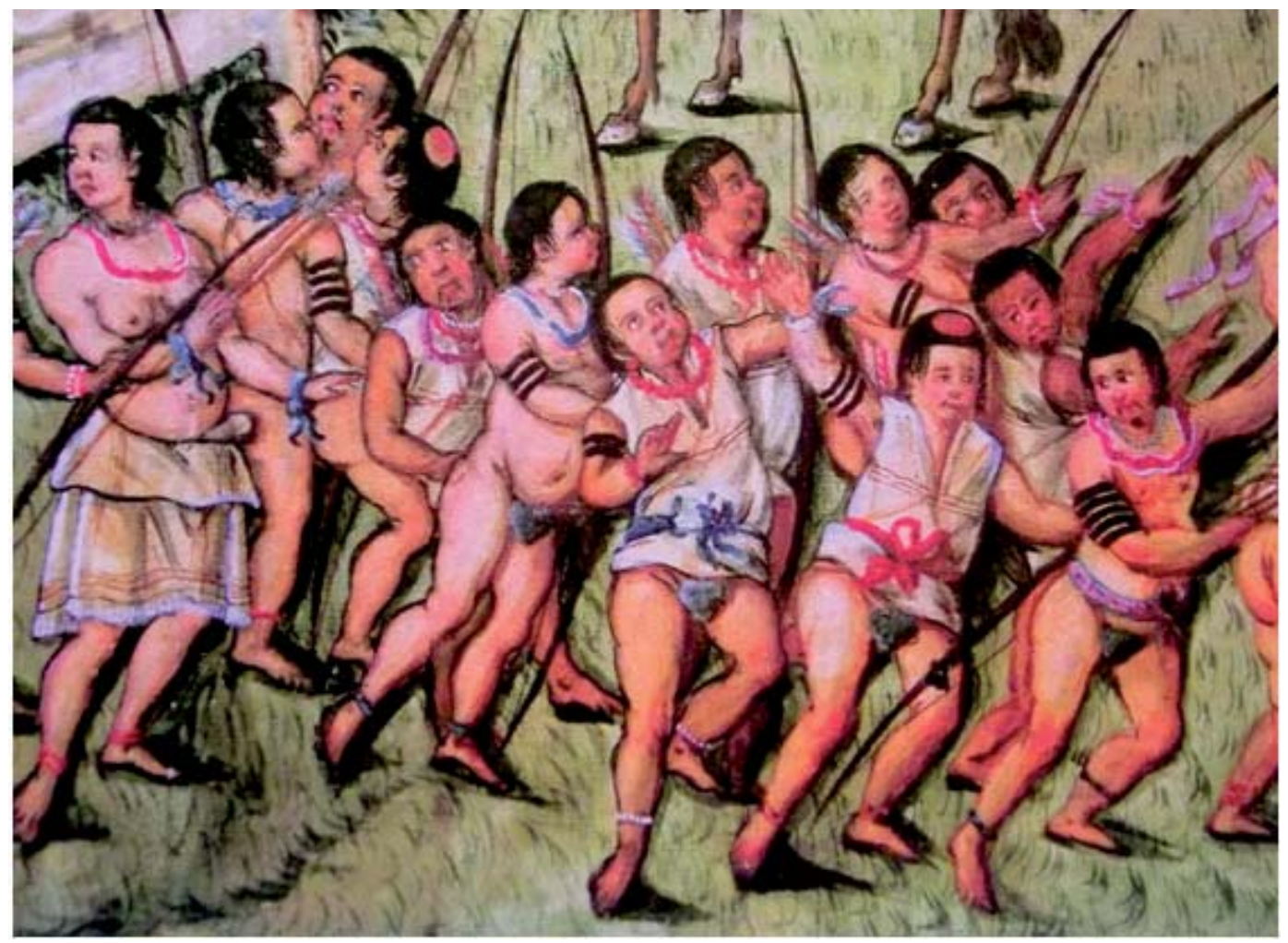

Figura 8 - Detalhe da cena trinta e sete, na qual os índios fogem do acampamento da expedição de Botelho, antes dos portugueses saberem que seis dos seus haviam sido mortos pelos indígenas

Fonte: Sampaio e Souza (1962).

Os desenhos das "coroas" na cabeça de alguns Kaingang nos lembram, outra vez, a velha questão de serem denominados em muitos relatos como "coroados", fato sobre o qual já traçamos alguns comentários no capítulo referente aos etnônimos dados aos Kaingang. É de se notar, no entanto, que dificilmente Miranda teria pintado tais "coroas" se não as tivesse visto pelos próprios olhos, ainda que, possivelmente, tenha feito os desenhos posteriormente.

No ano de 1865, o engenheiro Franz Keller desenhou o chefe Kaingang Manoel Aropquimbe, do aldeamento de São Jerônimo da Serra. Esse cacique também aparecia com os cabelos aparados em forma de coroa. Veja-se: 


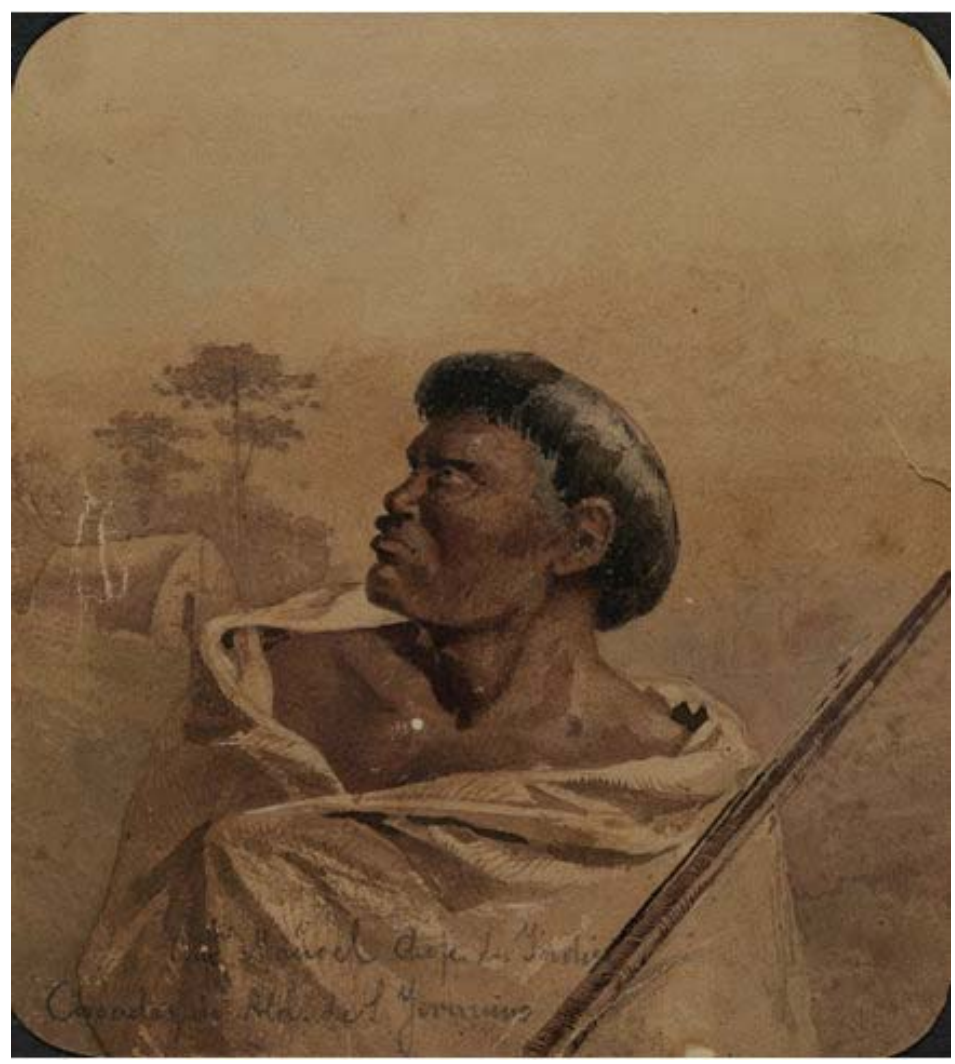

Figura 9 - O chefe Kaingang Manoel Aropquimbe, desenho feito por Franz Keller, em 1865, no aldeamento de São Jerônimo da Serra.

Fonte: Carneiro (1950).

Esse costume, no entanto, não deveria ser em sinal de obediência ou apreço aos religiosos capuchinhos, como querem alguns autores, pois, conforme relata frei Luiz de Cemitille, então diretor do aldeamento, o chefe Kaingang era duro e persistente nos seus velhos costumes pagãos, daqueles que se dizia incambiáveis, pois que a maldade nos velhos já haveria penetrado até a medula óssea. Daí a atenção que os missionários dedicavam, prioritariamente, às crianças, acreditando que nelas seria mais produtiva a obra de evangelização. Cemitille escreveu sobre o cacique Manoel:

Não me foi possível faze-lo compenetrar-se dos seus tristes erros, nem convence-lo de que a polygamia é um pecado. Devia contentar-se com uma só mulher em lugar de quatro (como tinha) em sua companhia. Muito menos persuadi-lo de que, morando comnosco, devia aprender a religião, para que tanto elle como 
a sua gente se tornassem, com o tempo, verdadeiros christãos e bons cidadãos. $\mathrm{O}$ velho polygamo em lugar de mostrar desejos de ser educado, respondeu-me que não podia deixar de ter as quatro mulheres, porque era Tremani (isto é valente). Se estava morando comnosco, continuou, não era por encontrar a felicidade, pois mais feliz se achava nas matas virgens, onde a caça, o peixe e a fructa eram mais abundantes, e nunca lhe faltara mantimento sufficiente para o próprio sustento e o da numerosa família. O verdadeiro motivo que justificava sua permanência entre nós era porque não podia passar mais sem as nossas ferramentas; que já era tarde para aceitar uma nova religião, sendo já velho, tanto que nunca poderá aprender a fazer o sinal da cruz. Emfim, despediu-se com uma risada e deu-me as costas, dizendo-me sarcástico adeus. (CEMITILLE apud MOTA, 1994, p. 254).

Assim, conduzir o indígena à "civilização", pela prática da fé cristã, seria o único bem a ser feito, salvá-lo do pecado do paganismo. Nesse sentido, devem-se lembrar os apontamentos de Clastres (2011, p. 80), quando explica que a justificativa do etnocídio baseia-se na premissa de que ele "é praticado para o bem do selvagem". O "problema" é que esses selvagens eram demasiadamente civilizados, formavam sociedades milenares, com organizações sociais riquíssimas, daí a impossibilidade de fazer desses povos uma "tabula rasa", inculcando-Ihes tudo o que se desejasse. Há, neste sentido, uma interessante página do Sermão do Espírito Santo, do padre Antonio Vieira, na qual o jesuíta escreve:

Há umas nações naturalmente duras, tenazes e constantes, as quais dificultosamente recebem a fé e deixam os erros de seus antepassados; resistem com as armas, duvidam com o entendimento, repugnam com a vontade, cerram-se, teimam, argumentam, replicam, dão grande trabalho até se renderem; mas, uma vez rendidas, uma vez que receberam a fé, ficam nelas firmes e constantes, como estátuas de mármore: não é necessário trabalhar mais com elas. Há outras nações, pelo contrário - e estas são as do Brasil - que recebem tudo o que lhes ensinam com grande docilidade e facilidade, sem argumentar, sem replicar, sem duvidar, sem resistir; mas são estátuas de murta que, em levantando a mão e a tesoura o jardineiro, logo perdem a nova figura, e tornam a bruteza antiga e natural, e a ser mato coma dantes eram. É necessário que assista sempre a estas estátuas o mestre delas: uma vez, que lhes corte o que vicejam os olhos, para que creiam o que não vêem; outra vez, que lhes cerceie o que vicejam as orelhas, para que não dêem ouvidos às fábulas de seus antepassados; outra vez, que lhes decepe o que vicejam os pés, para que se abstenham das ações e costumes bárbaros da gentilidade. E só desta maneira, trabalhando sempre contra a natureza do tronco e humor das raízes, se pode conservar nestas plantas rudes a forma não natural, e compostura dos ramos. (VIEIRA, 2000, p. 38). 
Essa passagem de Antonio Vieira inspirou, inclusive, um conhecido texto de Viveiros de Castro (2002) intitulado O mármore e a murta: sobre a inconstância da alma selvagem, no qual se mostra como o indígena é dissimulado mas persistente no seu modo de vida tradicional. Viveiros de Castro (2002) trata, neste texto, de povos Tupi, que seriam como a murta, como era a referencia em que se baseou para dar o título a seu texto. No entanto, a imagem metafórica tão bem construída pelo padre Antonio Vieira, serve também em relação aos Kaingang, tão resistentes nos seus velhos hábitos e costumes, à maneira do citado chefe Manoel, que expressara claramente ao frei Cemetille que se estava no aldeamento era porque Ihe interessava as ferramentas e objetos que só ali poderia obter, e não por estar disposto a aprender e viver os ensinamentos do frei.

Esse desengano que os missionários iam encontrar nas malocas indígenas por todo o Brasil nos faz lembrar uma passagem muito oportunamente narrada por Nimuendaju sobre os Apapocúva-Guarani, resguardando a diferença que, enquanto o chefe Kaingang manifestava abertamente seu desprezo pelos novos costumes que chegavam pelos fóg (não índios), o Apopocúva representava estar disposto a seguir fielmente os ensinamentos do missionário, como se nota no seguinte trecho:

Então vem o padre (católico) visitar-me na aldeia; eu o recebo tão bem quanto posso, mando matar uma galinha para ele e, à noite, preparar sua cama. $\mathrm{Na}$ outra manhã ele conta o que sabe, isto e aquilo; quando ele termina, digo eu: 'Sim, Senhor'; ele fica satisfeito e vai embora e diz: 'Este capitão sim, este é um bom capitão!' - Aí quando vem o ministro (protestante), também para ele mando matar uma galinha (quando tenho), e buscar mel no mato, porque não temos açúcar; ele me conta também a sua estória e eu ouço e respondo: 'Sim, Sr. Ministro.' E então ele fica satisfeito e diz: 'Este sim, este é um capitão de verdade!' E assim os vou tratando a todos. (NIMUENDAJÚ, 1987, p. 25).

Neste sentido, os apontamentos do padre Chagas Lima (1842) sobre a catequese por ele dirigida nos Campos de Guarapuava a partir de 1812 demonstram que mesmo os grupos Kaingang que foram aldeados continuavam a viver sua cultura tradicional. Chagas Lima (1842) relata, por exemplo, sua decepção com a vida desregrada do chefe dos Votorões, Hyppolito Condoi, cujas disposições, a princípio, pareciam boas. Conforme narra o padre, este Condoi, além de polígamo, era supersticioso, pois estando certa vez enfermo, em vez de recorrer a Deus, mandou fazer corpos de cera, formando, com penas de papagaios, duas figuras destas aves, as quais pôs sobre seu leito suspensas por duas linhas, de maneira que se moviam com a agitação do ar e da fumaça do fogo. Lima prossegue escrevendo que: 
A estas aves é que fazia seus votos com muita reverência, dizendo: longjó! longjó! cangatomy caraca pano tom, isto é, papagaio! papagaio! se eu sarar, nunca mais despedirei setas contra vós: no que se vê que temia morrer, e quanto era afferrado a seus principios, apezar das instrucç̧ões, já recebidas. Eram, contudo, dolosos, os seus votos; porque, apenas restabeleceu a sua saúde, fez uma grande caçada de papagaios, e logo depois foi para a guerra, levando para os sertões toda a sua família. (CHAGAS LIMA, 1842, p. 48).

O velho Condoi teria se alojado em uma campina além do Iguaçu, a trinta e duas léguas do aldeamento, formando uma aldeia de duzentas pessoas, vivendo em "deboche", até ser morto no ano de 1817. Chagas Lima (1842, p. 49) relata que os Votorões sempre tiveram "pouca persistência", pois depois de cinco meses aldeados, uma grande parte fugiu para os sertões. Contudo, vinham quase todos os anos e passavam alguns meses na aldeia, se deixavam batizar e depois se evadiam, levando consigo muitos outros de seu grupo. Diz o padre: "Eu os reputei semi-barbaros e difficeis de instrucção" (CHAGAS LIMA, 1842, p. 49). Era extremamente custoso desarraigar os índios dos seus "vícios antigos e deboches" em que viviam engolfados. Para o padre, os indígenas eram cruéis, vingativos e não davam mostras de religião. Os Votorões teriam sido os primeiros a formaram uma espécie de seita, "cujo principio era o de formarem bailes, que duravam toda a noite, embriagando-se com o koafé, em os quaes praticavam as maiores torpezas" (CHAGAS LIMA, 1842, p. 52).

Em outra passagem de sua "memória", Chagas Lima, depois de narrar os esforços do missionário para a conversão do gentio, escreve:

Mas os Indios aldeados foram como uma materia humana, que custa a incendiar-se, e isto lentamente, emquanto distrahidos em acções de guerra e calamidade que d'ahi resultam; preocupados com a indulgencia dos antigos vicios de sua barbaridade, correspondiam mui poço aos trabalhos e diligencia do seu director espiritual, e commumente a fé era n'elles muito enferma; elles não quizeram jámais abster-se de frequentar com excesso os bailes obscenos, entre bebidas embriagantes, a que davam o nome de koafé, quando eram fabricadas de milho, e koaqui, quando de pinhão; cujos entretimentos sempre acabavam em desenvolturas brutas: e quando eram arguidos, mettiam-se nos matos, em malocas, tanto os homens como as mulheres, em que gastavam dias e semannas com taes obscenidades. (CHAGAS LIMA, 1842, p. 55).

Chagas Lima (1842, p. 61) narra, ainda, que os índios pensavam na livre satisfação de suas paixões, acreditando que as almas iam para o céu sem diferença de mérito, como o sacerdote diz poder ter notado na cerimônia de seus enterros. Por 
isso, teriam eles desenvolvido "todas as sortes de iniquidades, repetidos actos viciosos de propensão para o mal da natureza corrompida" (CHAGAS LIMA, 1842, p. 61). Desse modo, viviam os índios desregradamente, com todos os "deboches" possíveis.

A partir desse contato mais intenso com a sociedade brasileira, os Kaingang foram sendo pressionados a abandonar seu modo de vida tradicional e absorver os elementos estranhos. É por isso que o indígena busca ocultar, ao máximo, tudo que possa denunciar sua verdadeira identidade, a não ser que confie no estranho o suficiente para que, por exemplo, as mulheres não façam a costumeira correria para esconder as comidas indígenas quando este chega em sua moradia. Em relação à espiritualidade, esse ocultamento é ainda mais acentuado. Baldus (1937) dizia, por exemplo, que os Kaingang de Palmas faziam esforços para praticar o culto cristão ao lado do seu culto aos mortos, isso, antes de tudo, para não que não fossem considerados inferiores aos seus vizinhos brasileiros" (BALDUS, 1937, p. 63). O autor narra, ainda, algumas anedotas do chefe Kõĩkãng:

Uma vez, o chefe Kõĩkãng me fez a seguinte comunicação: 'Dizem que os antigos Kaingang eram os primeiros em ter topẽ; mas como eles não sabiam rezar nem tratar com os santos, ele lhes foi roubado pelos portugueses. Hoje, temol-o outra vez porque aprendemos a rezar e a tratar com os santos'. - Eu não podia averiguar se os Kaingang receberam esta historieta também de um missionário ou se eles mesmos a inventaram. Quando perguntei a Kõĩkãng se ele poderia rezar como um cristão, respondeu: 'Esqueci'. (BALDUS, 1937, p. 65).

Nimuendajú (1987) relata que os Apapocúva viviam um cristianismo simulado, buscando esconder ao máximo sua religião dos regionais com os quais esses Guarani mantinham contato. Isso porque a "estúpida presunção religiosa" desses cristãos era tal que só reconheciam "como seres humanos seus correligionários, considerando o assassinato de um índio pagão tão pouco criminoso quanto a matança de um animal" (NIMUENDAJÚ, 1987, p. 27). Assim, o Guarani deixava-se batizar pelo cristão, guardando em segredo seu nome verdadeiro, se utilizando de um nome português ou espanhol nas relações com os não índios, afirmando, resignadamente, nunca ter tido outro. Também como forma de rechaçar os ataques cristãos, o Guarani se utilizava da cruz, tanto em suas "casas de dança", conforme expressão de Nimuendajú (1987), como também sobre os túmulos. Nimuendajú (1987, p. 28) diz, ainda, que "quando o visitante espirra, ele [o Guarani] diz: 'Deus Ihe ajude', antes de cada frase ele exclama: 'Nossa Senhora'", de modo que "envergonhada, a visita é obrigada enfim a reconhecer que estes animais desgraçados têm feito progressos notáveis 
no tornar-se gente" (NIMUENDAJÚ, 1987, p. 28). Diante de tudo isso, no entanto, o Apapocúva guardava, em seu íntimo, sua verdadeira religião. Em tom beirando o literário, Nimuendajú escreve:

Quando os Guarani estabelecem sua aldeia na vizinhança de moradores brasileiros, como é usual, naturalmente jamais conseguem ocultar de todo a sua velha religião. Pode-se ouvir nitidamente, a mais de meia légua de distância, dentro do silêncio noturno da mata, os sons estridentes dos cantos de pajelança, que evocam clarins, e as pancadas retumbantes da taquara de dança. O cristão é aí acometido de certo pavor, diante dessa prática misteriosa e incompreensível: afinal não se pode saber se estes sujeitos sinistros possuem mais conhecimentos de feitiçaria do que admitem; e muito cristão fervoroso já se confiou, em sua aflição, a um pajé índio, quando nenhum santo mais the queria valer. (NIMUENDAJÚ, 1987, p. 29).

Falamos dos Guarani não por comparação de caráter positivo ou negativo, mas na perspectiva de alteridade e resistência desses povos, afinal, o caso citado por $\mathrm{Ni}$ muendajú (1987) é exemplo notável de como os povos indígenas podem continuar sua cultura tribal em meio à esmagadora civilização dos jurua kuery³ (não indígenas).

Ainda em relação às estampas de Miranda, na cena dezesseis, vê-se que, mais uma vez, os militares tratam os Kaingang da melhor forma possível, Ihes presenteiam com vestes, facas, facões e machados, um gesto de bondade e ternura com o qual os soldados talvez esperassem conquistar a confiança dos indígenas. Isso também é o que se vê na cena de número dezessete:

\footnotetext{
${ }^{3}$ Contou-nos, certa vez, um cacique Guarani-Mbyá da aldeia Tapixi (Lebre), de Rio das Cobras, que juru'a, além da referência à barba (juru = boca + 'a = cabelo) refere-se ao fato de que os não indígenas falam demais, às vezes sem necessidade, e muitos deles falam em tom de voz muito alto.
} 


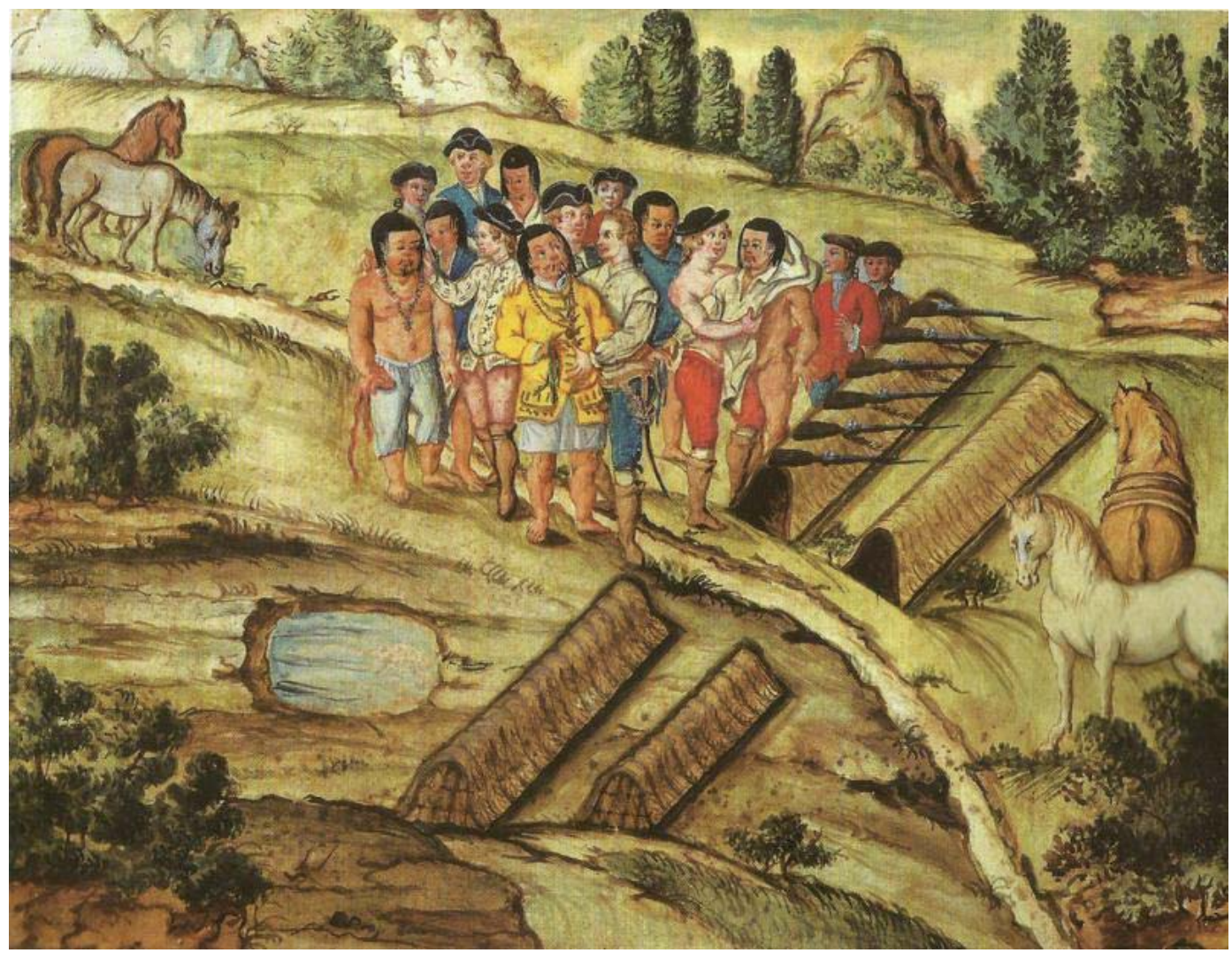

Figura 10 - Cena 17- O Tenente Coronel vestindo a sua propria vestia a hum Indio, e os mais Camaradas, despindo as suas camizas, e mais vestidos para vestir outros Fonte: Sampaio e Souza (1962).

Assim como no primeiro encontro com os índios, a expedição buscava agradar os Kaingang e ganhar a confiança deles com presentes e vestes. Nessa visita dos indígenas, Botelho conta que eles receberam muitas facas e facões, objetos que mais apreciavam, além de um machado, o qual, pelos acenos, teria sido muito estimado para tirar mel. Nessa visita, os Kaingang haviam se dividido em dois grupos, outros oito indígenas estavam escondidos na mata, com certeza, espreitavam tudo o que estava acontecendo (SAMPAIO E SOUSA, 1956, p. 33). Após serem bem recebidos, dois desses indígenas foram chamar os outros, que aguardavam a alguma distância. Pouco tempo depois chegaram esses oito indígenas, todos vinham armados com arco e flecha, como Miranda desenhou na cena de número dezenove: 


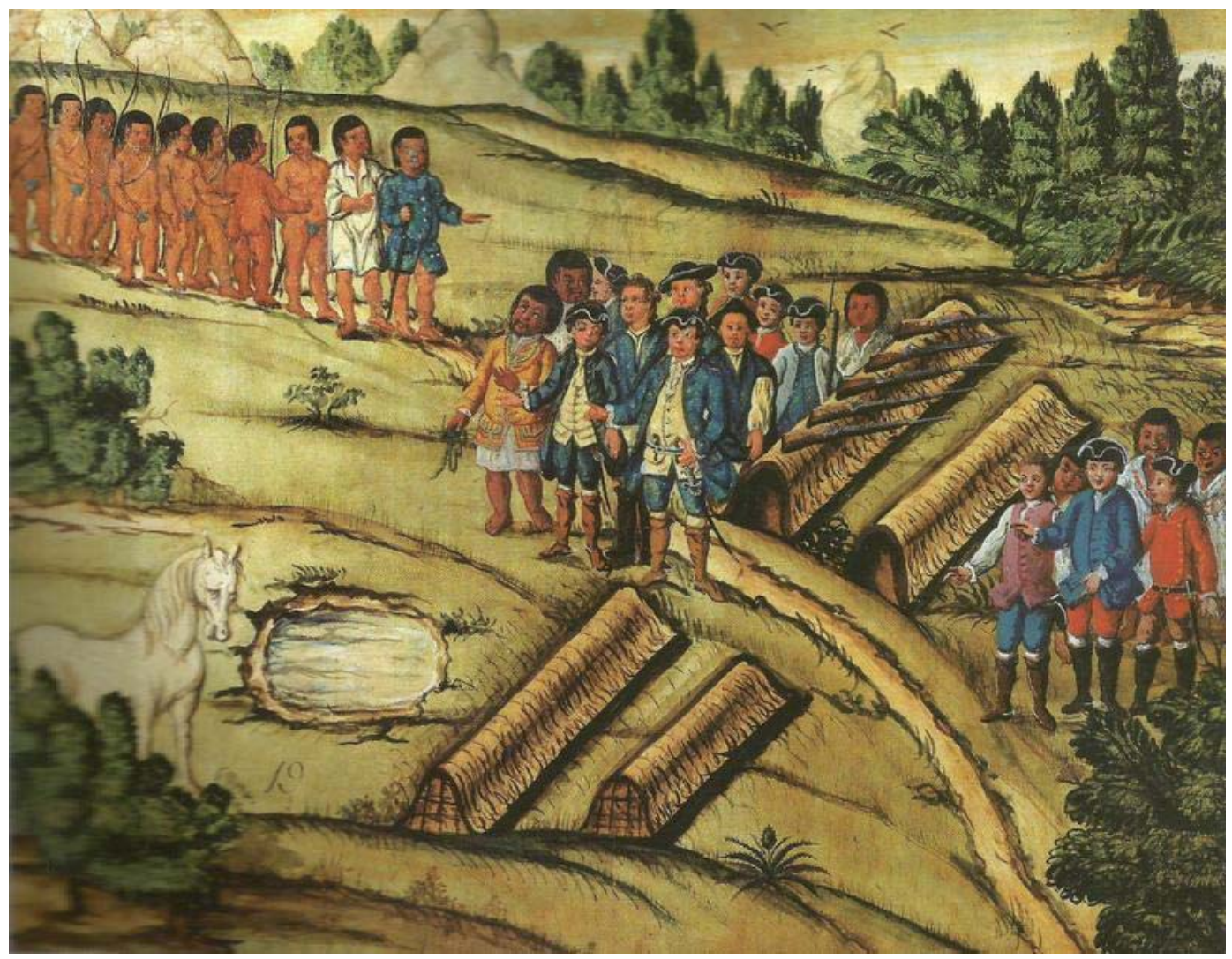

Figura 11 - Cena 19 - vem chegando mais Indios ao arranchamento, conduzidos pelos dois que já vestidos os forão chamar

Fonte: Sampaio e Souza (1962).

Além das facas e facões que já haviam recebido, os indígenas, agora, tiravam dos soldados as catanas das bainhas, pedindo também estas como presente, "mas para os devertir deram-se-lhe outras cousas, pedindo muito os botões das vestias por serem de casquinha reluzentes" (SAMPAIO E SOUSA, 1956, p. 33). Nesse momento, chegaram dois indígenas que haviam ido buscar pinhão em um lago, traziam bastante. Lançaram os pinhões ao terreiro e fizeram fogo em cima, oferecendo e ensinando aos soldados como eram consumidos. Como recompensa, os homens de Botelho trouxeram ao terreiro um quarto de porco assado, mas os indígenas se recusaram a comer, convidando os luso-brasileiros para visitá-los em suas moradias. A recusa indígena se dava, provavelmente, porque duvidavam das boas intenções dos fóg, já que era uma prática indígena envenenarem alimentos, como fizeram, poucos dias 
depois, quando armaram a emboscada que sepultou sete dos homens de Botelho nos Campos de Guarapuava: "[...] se observou depois serem invenenados uns bolos, que traziam, e deram a alguns camaradas, porque um cão, que comeu deles, logo morreu, e dous mais, que duraram até o outro dia" (SAMPAIO E SOUSA, 1956, p. 45).

Na cena de número vinte, o tema ainda é oferta de roupas e brindes aos indígenas, o mesmo acontece na cena de número vinte e um. Apresentamos a primeira dessas cenas:

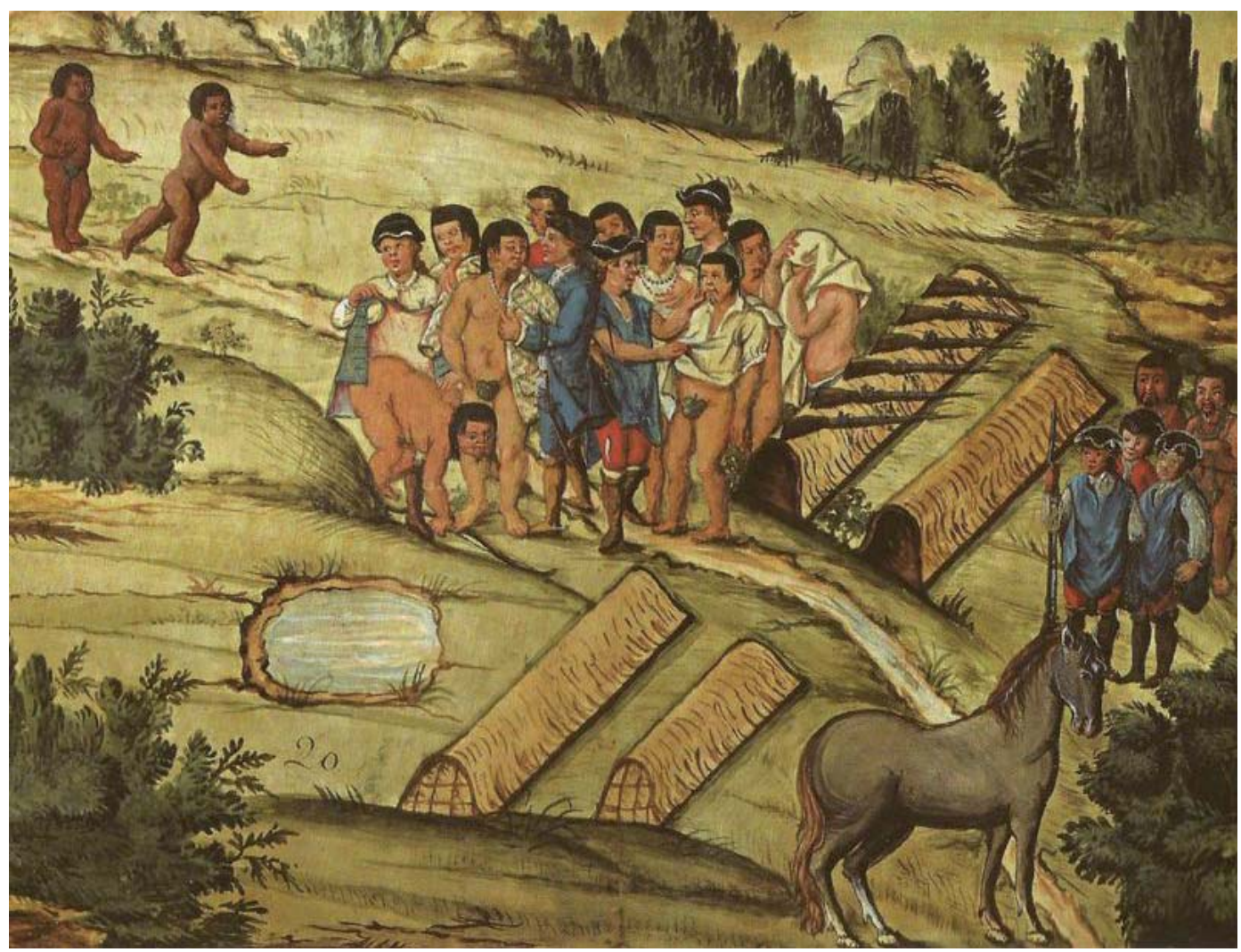

Figura 12 - Cena 20 - Chegão os novos Indios ao arranchamento, tirão os Camaradas da sua rôpa quanto puderão até ficarem alguns sem camiza, e só com ponches cubertos, e os vestem Fonte: Sampaio e Souza (1962).

Os indígenas, nessa visita, após deixarem alguns arcos e flechas como presentes aos fóg, foram embora dizendo que lhes esperariam em suas casas. Nesse mesmo dia, na parte da tarde, Botelho e alguns oficiais foram pagar a promessa feita aos 
índios. Após cerca de uma légua e meia de marcha, a cavalo, os soldados avistaram a "rancharia" dos indígenas. Essa visita é representada em cinco cenas, as de número vinte e dois a vinte e seis. Na cena vinte e dois, que apresentamos abaixo, Miranda desenha a chegada dos soldados, com destaque para os cães, os pinhões no riacho e os "arranchamentos" indígenas.

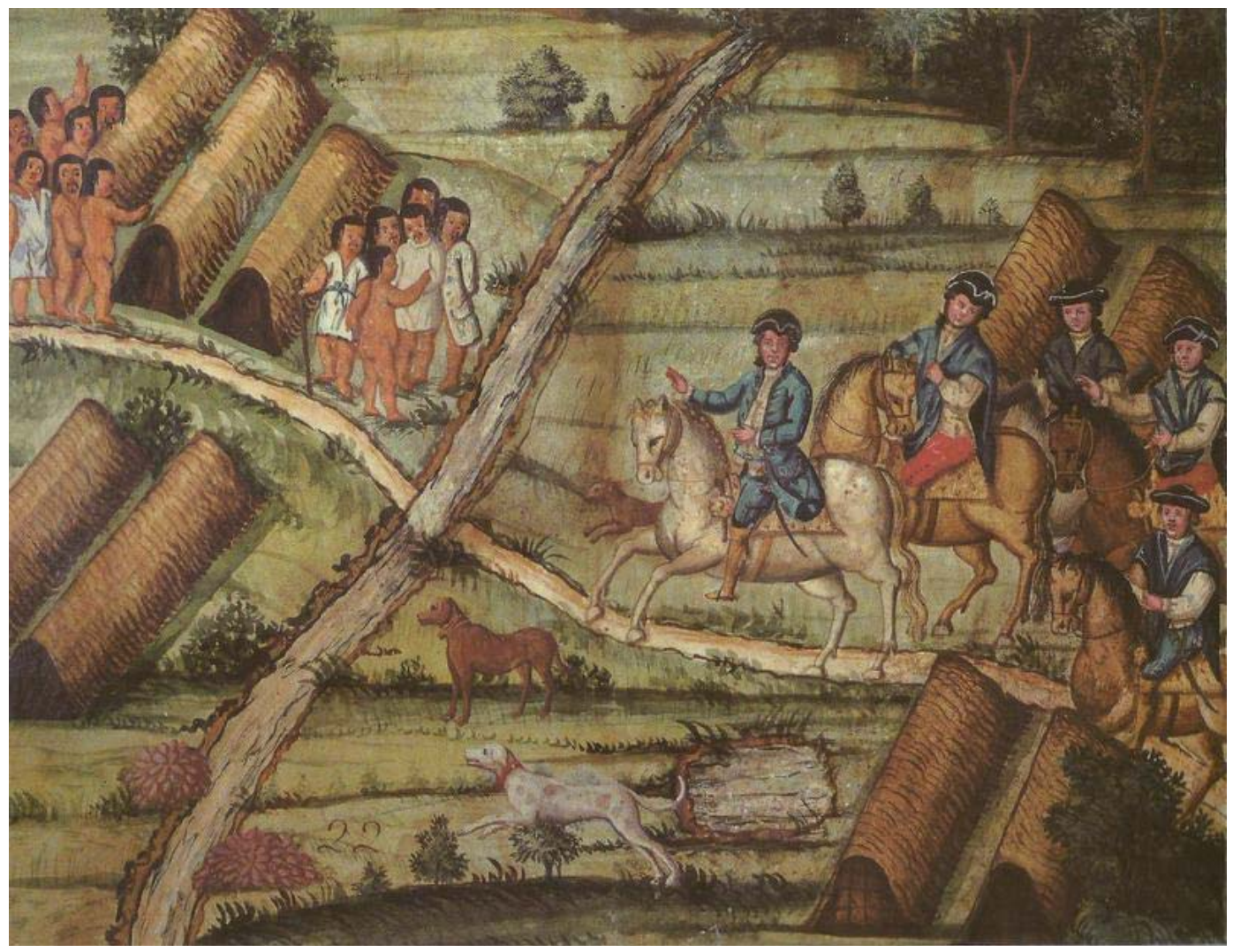

Figura 13 - Cena 22 - parte o Tenente Coronel á arrancharia dos Indios, que tanto que o virão alvoracados o esperão Fonte: Sampaio e Souza (1962).

Os índios convidaram os soldados a entrarem em suas casas, pois caía uma chuva torrencial, ao que o tenente-coronel teria atendido "para mais agradar" os indígenas. Da mesma forma que se dá o contato com vários outros povos indígenas, não havia mulheres e crianças entre os Kaingang que receberam os soldados em seus ranchos, haja vista que essa visita já era esperada. Isso significa não somente que estavam preparados para lutar, caso fosse necessário, mas que esse confronto, para 
eles, era bastante possível, pois já sabiam das intenções dos fóg. O próprio Botelho bem observa esse fato:

Continuaram-se-Ihes algũas pequenas dádivas, convidando-os viessem ao pôrto, onde havia muito, que lhes dar, o que êles prometeram fazer, dando mostras de trazerem suas mulheres, e filhos, que para isso os tinham já mandado vir da aldeia principal, corando com isto a cautela, que tinham tido de pô-las fora do alojamento, conservando nêle sòmente os que podiam usar de armas, no que bem mostraram o receio, que tinham de que houvesse em nós traição; mas como não viram mostras, nos pediram muito ficássemos lá, pois tinham mandado caçar, e melar para Pahy, que assim tratavam ao dito tenente-coronel comandante, e pegando na mão a alguns camaradas, que fôssem com êles para the darem de comer onde tinham as mulheres, e filhos, mostravam, que muito breve voltariam, faltavam alguns dos que pela menhã tinha[m] ido ao nosso pouso, e estavam outros, que lá não tinham ido, e dos trastes, que se Ihes tinham dado poucos tinham já. (SAMPAIO E SOUZA, 1956, p. 35).

É interessante nesse trecho, ainda, o registro de que os índios tratavam o comandante da expedição pela designação pahy, sendo que pãa'i (fala-se "põ'i"), em Kaingang, quer dizer "líder", "cacique", de modo que temos aqui o registro de uma palavra Kaingang feito no século XVIII.

Essa visita foi rápida. Antes da partida, os índios ofertaram um tição de fogo aos soldados, "[...] o que se entendeu ser entre êles grande fineza pelo muito que Ihes custa a acender" (SAMPAIO E SOUZA, 1956, p. 35). Realmente, os Kaingang mais velhos contam que, antigamente, o fogo era mantido sempre aceso, pois era bastante custoso acendê-lo. Um dos nossos melhores informantes de Rio das Cobras, nosso avô João Maria Gojkág Capanema, nos disse que ainda sabe acender o fogo por meio do processo de fricção, mas já os braços não lhe são fortes o suficiente para isso. O modo por ele descrito consiste em fazer um pequeno encaixe na extremidade inferior de um ramo seco de palmeira, onde será posta uma vareta roliça que ficará entre as mãos daquele que produzirá os movimentos de fricção. Esse processo pode demorar vários minutos, até que os movimentos façam com que pequenas partículas da palmeira se soltem e fiquem no fundo desse encaixe, as quais, aquecidas, se transformarão em fogo, em volta do qual se colhem os mais frutíferos dados para o conhecimento de uma cultura indígena.

Além do tição de fogo, um dos índios ofertou a Botelho um bordão, um arco e uma flecha, sendo retribuído com um lenço vermelho e as ligas das pernas, que era o que tinha o tenente-coronel para lhe dar, ficando o índio com isso satisfeito. 
Outros índios deram suas flechas e arcos aos homens de Botelho, prometendo fazer muitas outras e levar ao acampamento dos luso-brasileiros (SAMPAIO E SOUZA, 1956). No relatório de Botelho, consta ainda que os índios fizeram uma "grande galhofa" quando a tropa partiu, marchando os homens com as flechas e arcos indígenas. Em uma das estampas, Miranda retrata esse acontecimento. Veja-se:

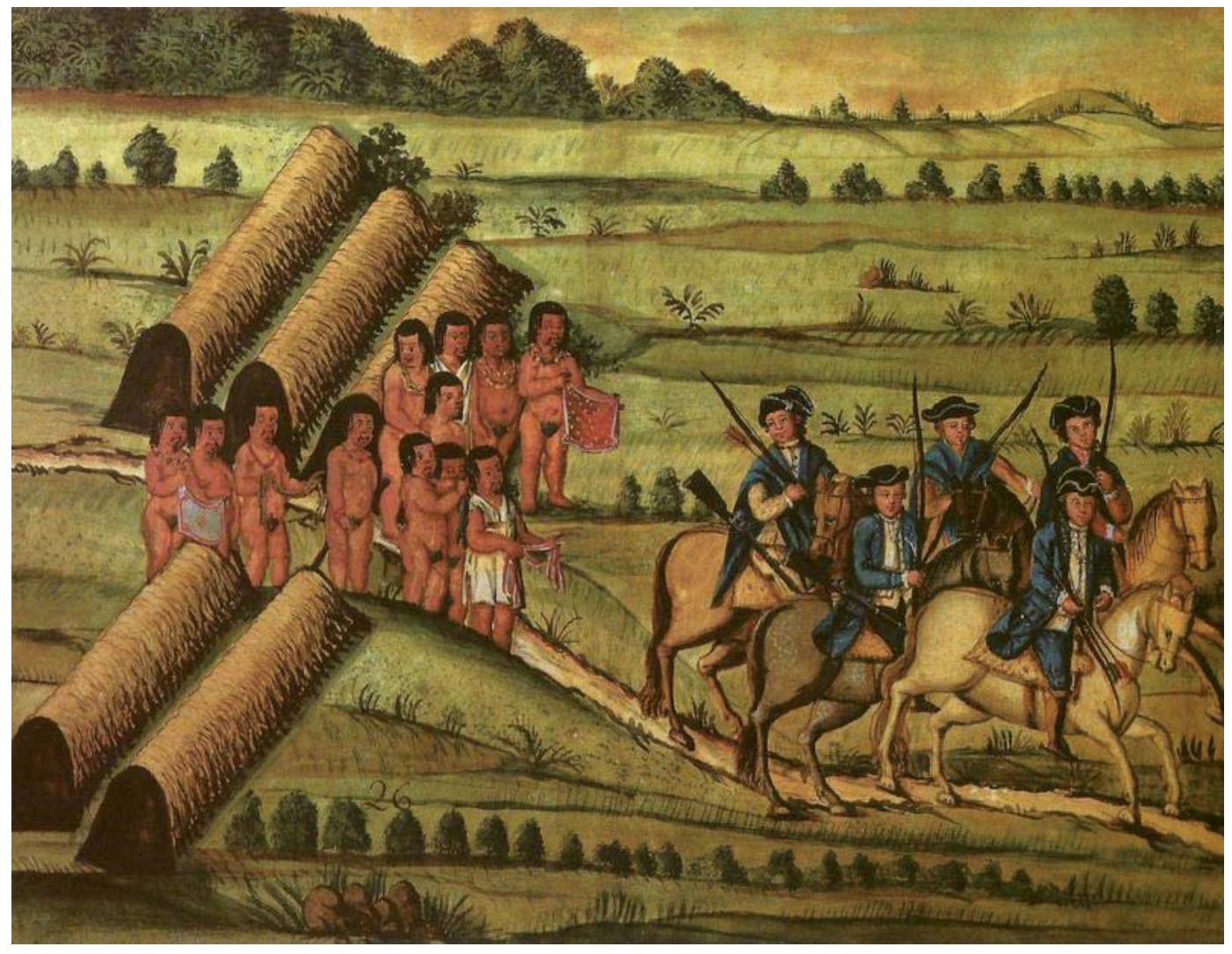

Figura 14 - Cena 26 - marchando o Tenente Coronel, e Companheiros com arcos, e flexas dos Indios e estes mostrando algumas couzas, que lhe deixou Fonte: Sampaio e Souza (1962).

A partir dessa visita aos indígenas, começava-se a crer que era possível conquistar, brandamente, esse povo pagão para o grêmio cristão. Neste sentido, consta no relatório de Botelho que Deus principiava "a abrir as portas da sua Divina Misericórdia a êste gentilismo, que nunca se presumiu achar tão humano, e tratável como se experimentou" (SAMPAIO E SOUZA, 1956, p. 36). O retorno da tropa ao acampamento se dá no dia 18 de dezembro, após os soldados terem de pousar nos 
campos, sob chuva intensa, episódio também retratado por Miranda em uma das estampas.

Cinco dias depois, no dia 22 de dezembro, por volta das sete horas da manhã, alguns índios aparecem em um alto, defronte ao porto. Percebeu-se que outros indígenas, receosos, observavam o acampamento escondidos na mesma "lomba". Para demonstrar as intenções pacíficas que a tropa movia em relação aos indígenas, Botelho ordenou que seus homens, curiosos em ver os visitantes, não se movessem das barracas, nem pegassem em armas, mandando que alguns poucos homens passassem o rio em uma canoa para receber os índios. Estes, no entanto, preferiram cruzar por uma cachoeira, procurando, logo de isso terem feito, ao comandante Botelho, que os recebeu em sua barraca, o que teria deixado os índios muito contentes.

Essa visita era composta por cerca de setenta indígenas, aos quais Botelho deu "[...] tangas pintadas, facas, contas, e outras infinitas cousas, que estavam preparadas" (SAMPAIO E SOUZA, 1956, p. 37), fazendo os índios balbúrdia tamanha que não se pôde "[...] fazer verdadeiro cômputo de tudo quanto levaram" (SAMPAIO E SOUZA, 1956, p. 37). Botelho relata, também, que dos primeiros que chegaram à barraca "[...] foi ũa moça, que teria dezasseis anos pouco mais, ou menos, bem feita, que se andasse tratada não se conheceria por índia: trazia ũa tanga cingida pela cinta, que Ihe dava por cima dos joelhos sem mais compostura algũa" (SAMPAIO E SOUZA, 1956, p. 37). Para essa moça, deu-se uma "tanga de sofolié", baeta vermelha, ao pescoço várias miçangas, pente na testa e chapéu na cabeça, o que a deixou, sem dúvida, muito alegre. É necessário mencionar, ainda, que, se verdadeira, é ao menos intrigante a afirmação de que a moça "[...] foi dizer aos seus tanto que saiu da barraca, que estava muito bonita, o que se lhes percebeu por ser quase na língua da terra" (SAMPAIO E SOUZA, 1956, p. 37).

A essa visita são dedicadas três estampas de Miranda, as cenas de números vinte e oito, vinte e nove e trinta. As duas primeiras cenas dessa sequência tratam da chegada dos índios e dos presentes que Ihes foram dados; a última retrata a retirada dos indígenas. Veja-se a cena de número vinte e nove: 


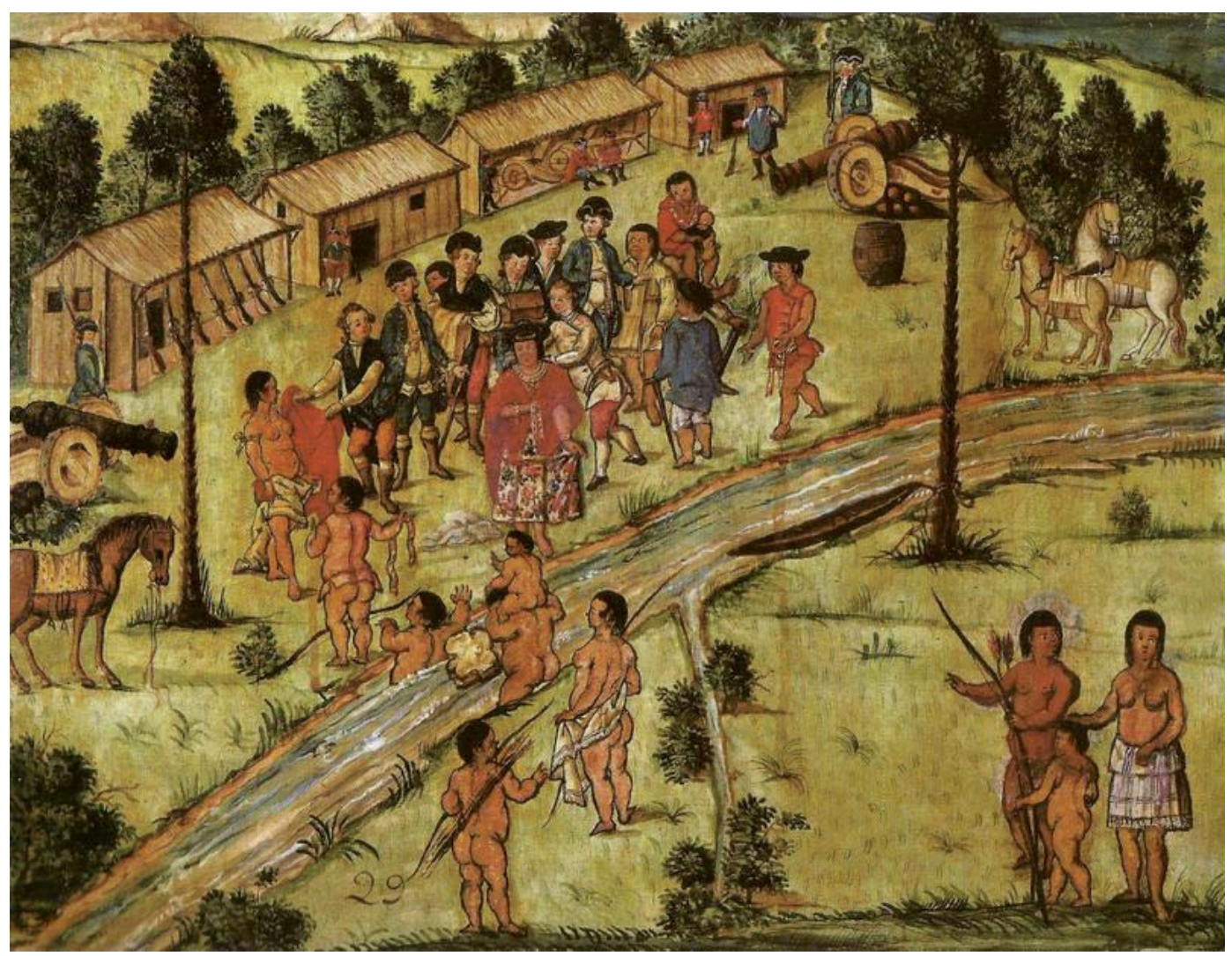

Figura 15 - Cena 29 - manda o Tenente Coronel vestir os Indios, e outros vão passando o rio com mulheres, e filhos às costas

Fonte: Sampaio e Souza (1962).

Entre os visitantes, estavam mulheres e vários rapazes de oito anos para cima, com destaque para um que teria dez anos, o qual "[...] não parecia índio criado nestes sertões, mas sim rapaz nascido em ũa terra civilizada" (SAMPAIO E SOUZA, 1956, p. 38). Tudo quanto viram, os índios levaram: machados, facas, foices etc. Havia também tocadores de viola na tropa, um deles, Roberto André, tocou viola e dançou, sendo que os índios, contentes, também dançaram a seu modo, "[...] com fortes diligências para levarem a viola, bolindo muito nas cordas, e com admiração examinando o que tinha por dentro" (SAMPAIO E SOUZA, 1956, p. 38).

Por volta das dez horas da manhã, os índios partiram do acampamento, deixando muitas flechas e arcos aos homens da tropa de Botelho, dando a entender que iriam buscar as mulheres e voltariam, no entanto, "[...] quase se lhes percebia, que 
queriam ir com Pahy" (SAMPAIO E SOUZA, 1956, p. 38). O motivo pelo qual queriam levar o comandante não se pode saber, mas a hipótese de que o eliminariam deve ser considerada. Uma tropa sem o seu comandante, em lugar desconhecido, povoado por indígenas, dificilmente teria disposições para prosseguir em seus objetivos. Talvez por isso tivessem vindo com mulheres e crianças, com mostras de confiança e amizade. Na cena trinta tem-se a retirada dos indígenas:

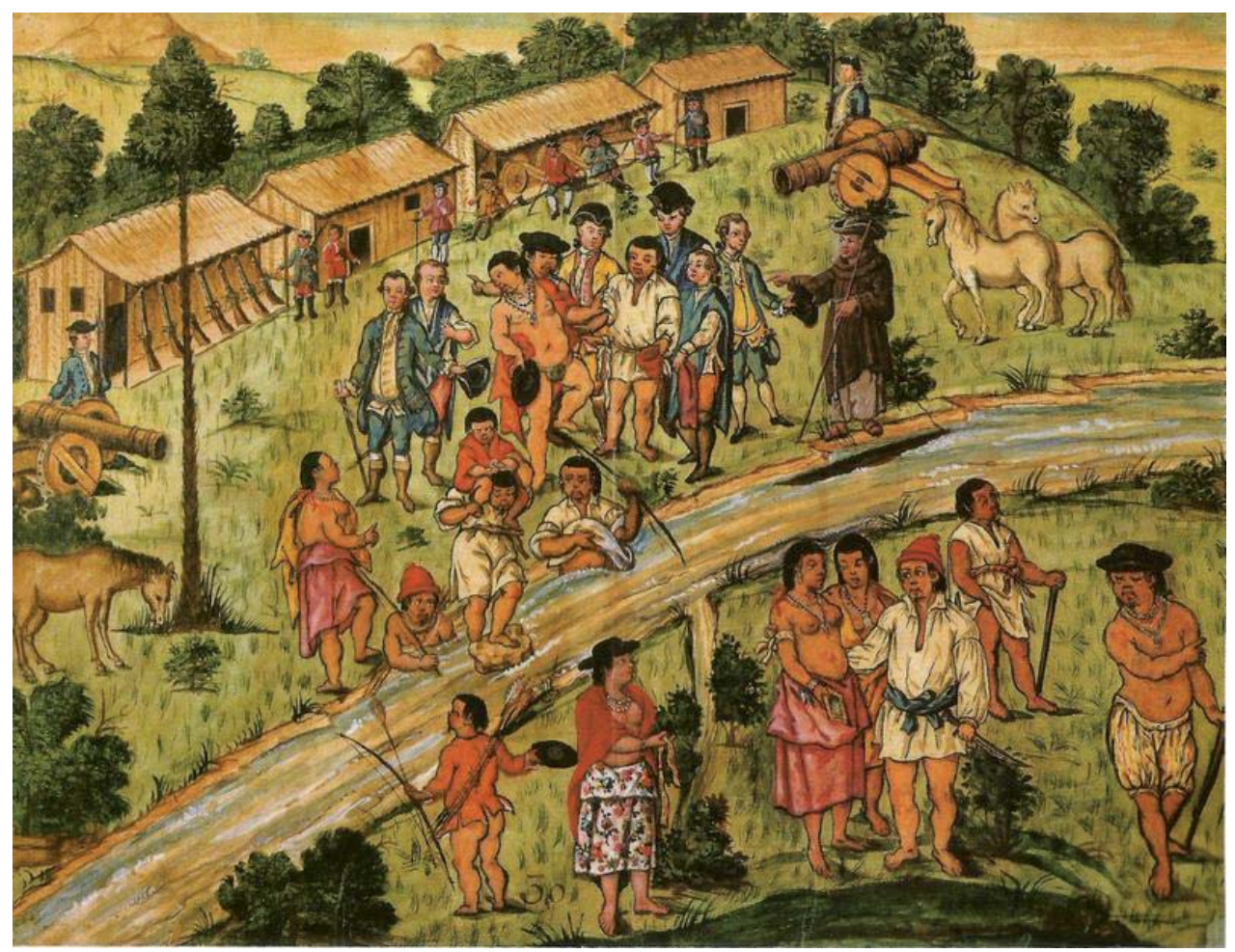

Figura 16 - Cena 30 - vão-se retirando os Indios muito alegres, e ad'mirados da liberalidade, que se uza com elles, pellos brincos, e vestidos, que se the derão Fonte: Sampaio e Souza (1962).

Depois de os índios terem deixado o acampamento, se preparou o altar para o capelão dizer missa "[...] e se deram muitas graças a Deus por tão bons princípios para redenção dêstes pagões, pela esperança, que ficou de recolher ao grêmio da Igreja êste disperso rebanho" (SAMPAIO E SOUZA, 1956, p. 38). Com essa visita, parece que crescia a confiança dos portugueses no sucesso de conquista da expedição. "O gentio" estaria "assombrado" com tamanha afabilidade encontrada nas ações da tropa de Botelho, no entanto, observa-se que estavam sempre vigiando 
os movimentos dos fóg, como consta no relatório que deixavam "sentinelas", pois narra-se, por exemplo, que, certo dia, uma jaguatirica que alguns militares haviam caçado próximo ao acampamento - deixando-a por algum tempo em uma trilha na mata - não mais foi encontrada, tendo eles notado que os indígenas a tinham levado.

Do dia vinte e dois de dezembro a oito de janeiro, aconteceram vários encontros entre os militares e os indígenas, durante as caçadas que os homens de Botelho faziam ao redor do acampamento, ou mesmo em suas expedições mais distantes, em busca de conhecer a região, quando, por várias vezes, avistaram habitações indígenas, encontraram moradias com vários artefatos por eles produzidos, dos quais levaram alguns, deixando alguns trastes em troca. No entanto, nesse período de duas semanas, não há nenhuma visita dos indígenas ao acampamento da tropa. Nesse tempo, os índios estudaram os movimentos dos fóg, observaram suas armas e constataram que o confronto direto não era o mais conveniente. Como escreve Mota (1994, p. 117), "o procedimento dos Kaingang em torno da expedição revela um senso apurado de como fazer a guerra".

No dia oito de janeiro de 1772, logo de manhã, cerca de quinhentos Kaingang surpreenderam a tropa de Botelho em seu acampamento. Nesse momento, Botelho saía com alguns homens para ver o lugar em que pretendia construir uma fortaleza. Botelho, então:

Suspendeu logo a viagem voltando para o quartel, fazendo aprontar as roupas, que se tinham feito para vestir as mulheres, e o mais, que a todos se havia de dar, dando ordem ao sargento Manoel Gomes, e tenente Cândido estivesse cada um pronto na sua peça de artelharia para dar fogo; e as mais armas, e corpos da guarda com as cautelas necessárias, sem dar suspeita aos índios desconfiávamos deles, e sem embargo de ser maior o número do que costumava vir, não causou horror à nossa tropa, pelas repetidas vêzes que os tinham visto ali os caçadores na caça, os campeadores no campo, e enfim o tenente-coronel, e os mais camaradas nos seus próprios alojamentos, onde é inexplicável o perigo a que se exposeram. (SAMPAIO E SOUZA, 1956, p. 43).

Os índios vinham tocando suas "gaitas de taquara", logo cruzaram o rio e foram bem recebidos pelo comandante Botelho. Vinham também mulheres "[...] que logo foram vestidas, e adornadas de saias, camisas, bajós, contas, miçangas, brincos, e espeIhos, e muitas mais cousas que lhes estavam preparadas" (SAMPAIO E SOUZA, 1956, p. 43). Os homens foram também presenteados com "tangas de chitas riscadas" e tudo 0 que mais Ihes apetecia. Incomodou a Botelho, ao que parece, a demasiada "franqueza" 
dos indígenas, os quais "entravam pelos ranchos, chegando alguns a tomar machados, e foices, e até uma baioneta, sem esperar que se lhe desse, o que tudo dissimulou o tenente-coronel para os não desagradar" (SAMPAIO E SOUZA, 1956, p. 43). Na seguinte estampa, Miranda retrata o alvoroço causado pelos índios nessa visita. Veja-se:

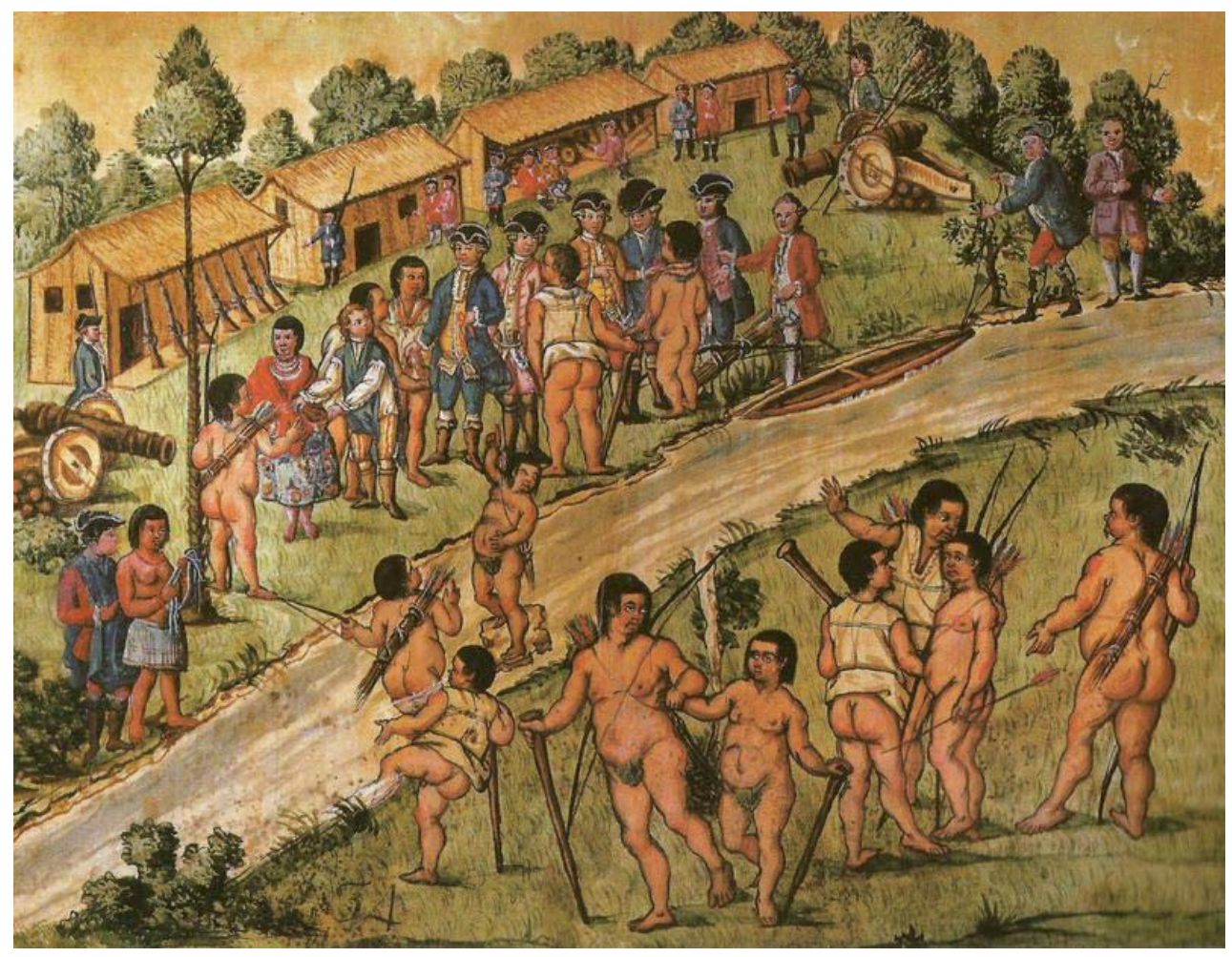

Figura 17- Cena 34 - convidão-se os Indios, veste-se huma India com vestidos de chita, que se lhe tinhão preparado, e ás mais se Ihe dão varias péssas Fonte: Sampaio e Souza (1962).

Nota-se, aqui, que os indígenas estão armados. Entravam nos ranchos e tomavam tudo quanto podiam, principalmente ferramentas, facas e outros objetos cortantes. Botelho não queria desagradar os indígenas, mas desconfiava da traição, por isso, as armas de fogo, entre elas dois canhões, foram cobertas, sendo que alguns homens protegiam esse arsenal. Os índios trouxeram

[...] milho verde, que ofertavam, e na mesma forma bolos do mesmo tão asquerosos, que só o desejo de os agradar tirava o horror de os aceitar, sendo dificultoso o achar meios de disfarçar comê-los, no que instavam fortemente. (SAMPAIO E SOUZA, 1956, p. 43). 
A insistência dos índios para que os homens de Botelho comessem o milho verde e os "bolos" era porque estavam envenenados, como já destacamos o trecho do relatório no qual se anota: "[...] se observou depois serem invenenados uns bolos, que traziam, e deram a alguns camaradas, porque um cão, que comeu deles, logo morreu, e dous mais, que duraram até o outro dia" (SAMPAIO E SOUSA, 1956, p. 45).

Com "impertinentes carinhos", conforme se escreve no relatório de Botelho, indígenas trabalharam para tirar do acampamento o tenente-coronel, do mesmo modo tentaram praticar com outros homens, entre eles alguns capitães, "[...] querendo-os levar às costas, e conduzi-los aos seus arranchamentos" (SAMPAIO E SOUZA, 1956, p. 43-4). Veja-se como Miranda pintou este acontecimento:

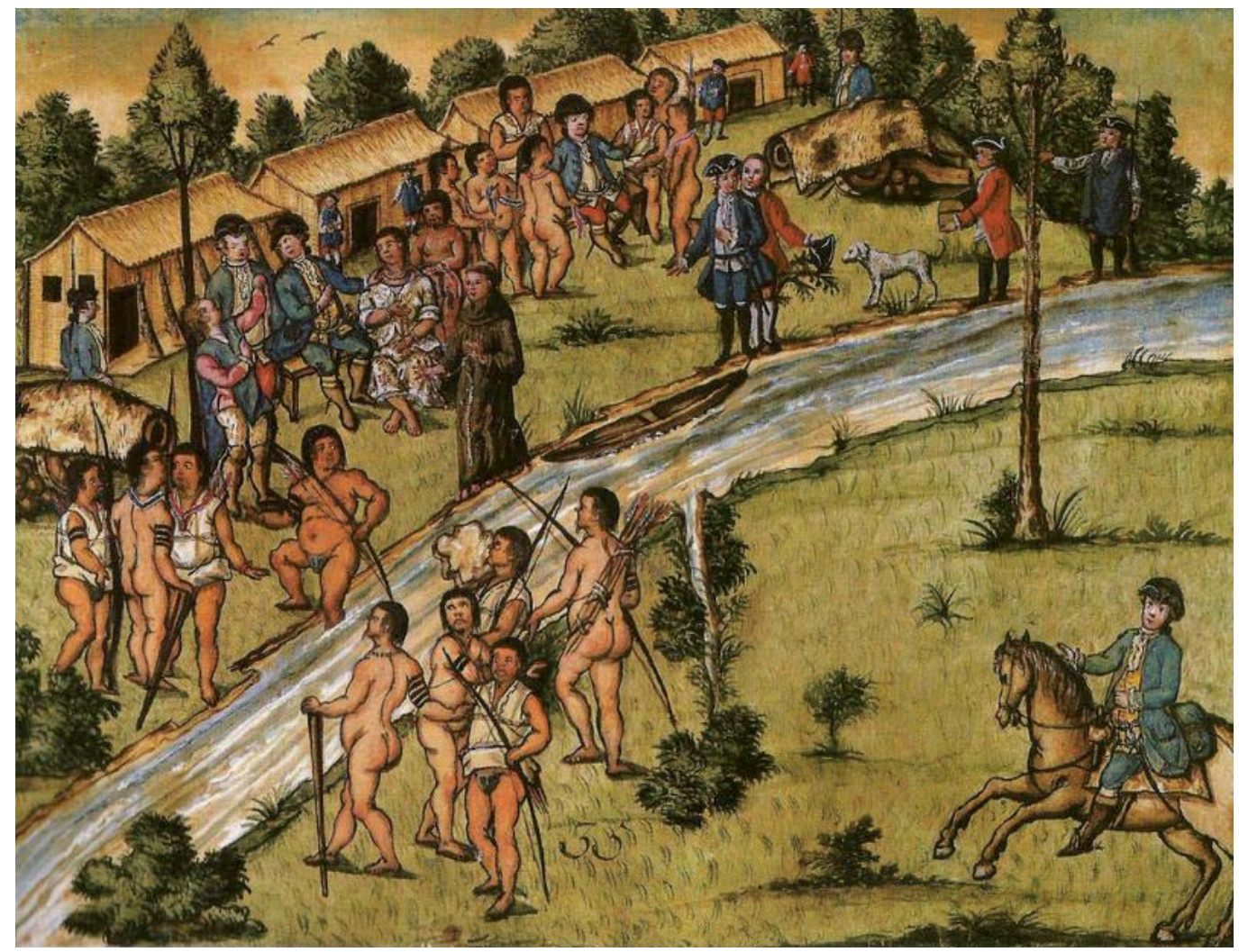

Figura 18- Cena 35 - o Tenente Coronel assentado com seis indios piquenos, e hum por detras esperando oucazião de matalo, os Cappitae's, e outras pessoas com o Padre Capellão com huma India pé cathequizando-a, e os Indios esperando oucazião de matar a todos

Fonte: Sampaio e Souza (1962). 
Observe-se que os canhões estão cobertos e dois homens os guardam. Interessante, também, são os braceletes ou pinturas nos braços dos indígenas, o que não aparece em cenas anteriores às dessa visita de oito de janeiro.

Com os "impertinentes carinhos" indígenas, caíram na imprudente resolução de cruzar o rio sete homens de Botelho, além do capitão Carneiro, que ia montado a cavalo. Dali:

[...] persuadidos dos carinhos daqueles bárbaros os acompanharam até encobrir-se com a lomba, que ficava quase meia légua distante do abarracamento, levando-os com muitos folguedos, e brincos até onde estavam em um vale grande multidão de gentio que tinham ficado escondidos, e ali os fizeram perecer com muita crueldade, que bem mostrava a tirania bárbara dos seus corações. (SAMPAIO E SOUZA, 1956, p. 44).

O capitão Carneiro, que ia a cavalo, teve a sorte de ter parado para tomar água, sempre rodeado por vários índios, podendo ver antes que estes - por estar montado - que, mais a frente, um dos seus camaradas estava morto no chão. Conhecendo a traição, dissimulou e pôde fugir, não sem ter de contar com a sorte - que mais era o cavalo - para escapar da chuva de flechas que os índios atiraram. A cena de número trinta e seis, que representa a morte dos homens de Botelho pelos indígenas, é, a nosso ver, uma das mais simbólicas e fortes do conjunto das estampas de Miranda, por ser a que, ao mesmo tempo, resume a resistência (na perspectiva Kaingang) e a barbárie e a traição (na perspectiva de Botelho). Para os nacionais, crueldade dos "bugres selvagens", para os indígenas, uma forma legítima de defender um território que habitavam há vários séculos. Veja-se a estampa: 


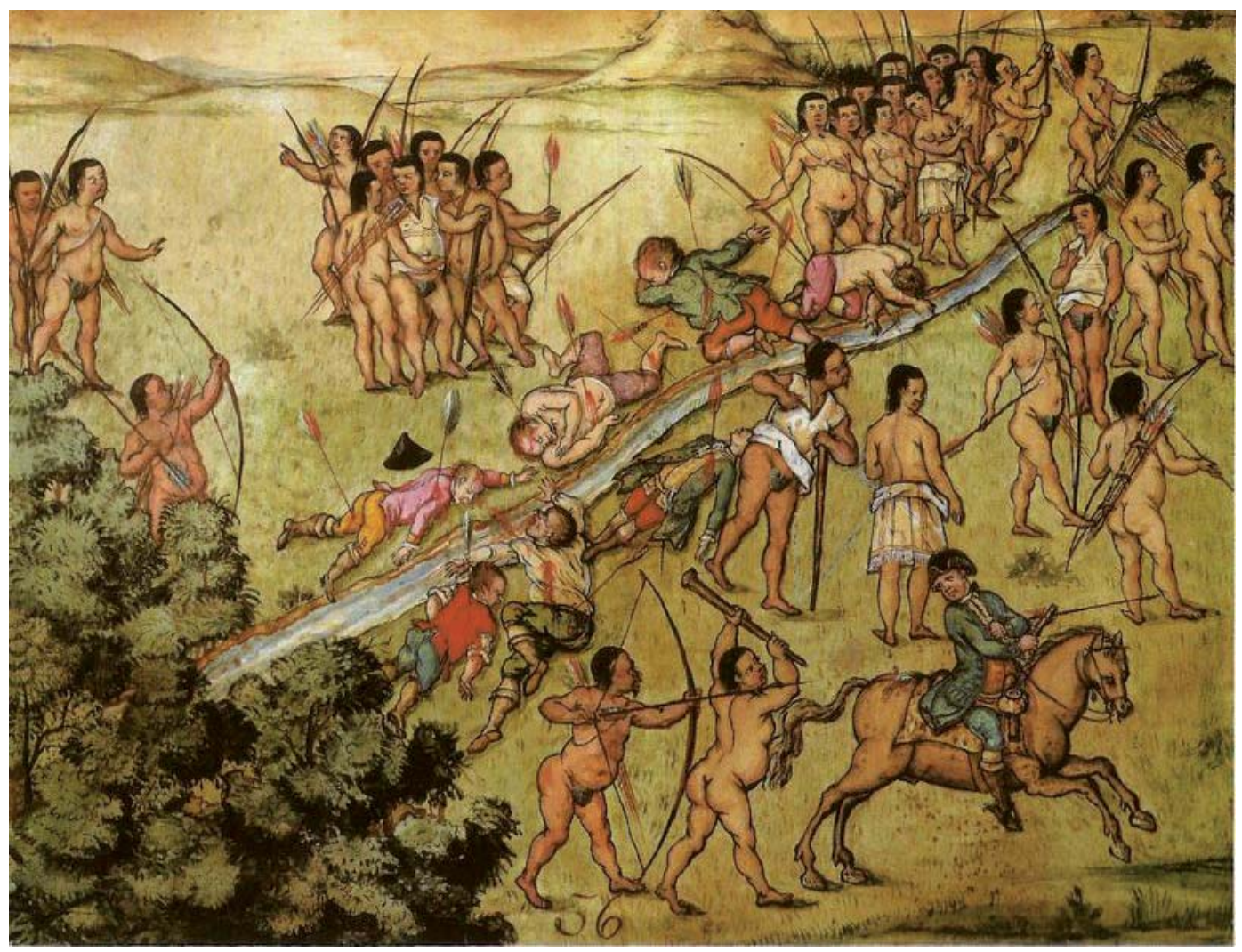

Figura 19 - Cena 36 - o Cappitão Carneiro que passou alem do rio com outros Camaradas, ficando estes mortos, veyo fogindo

Fonte: Sampaio e Souza (1962).

Logo após o massacre dos homens de Botelho, tem-se a fuga dos indígenas que estavam ainda no acampamento, pois que haviam sido avisados por seus companheiros, talvez servissem para isso as "gaitas" de taquara. Sabendo do acontecido, Botelho enviou o tenente Cândido Xavier com alguns homens para procurar os companheiros. No primeiro vale que entraram os homens, já em lugar que não podia ser avistado do acampamento, o tenente:

[...] achou os corpos de seis camaradas mortos, passados com flechas, e algũas nos mesmos corpos tão maltratados, que metiam horror, e compaixão, distantes um dos outros cousa de tiro de espingarda, e todos em um regato, que passa pelo meio do campo; o camarada José Pinto com vida, ainda que todo maltratado, e com algũas flechas cravadas no corpo. (SAMPAIO E SOUZA, 1956, p. 45-46). 
Vendo os companheiros mortos, o tenente mandou que seus homens os recolhessem, além de mandar chamar o padre para confessar aquele que ainda vivia, como se vê na cena de número trinta e oito:

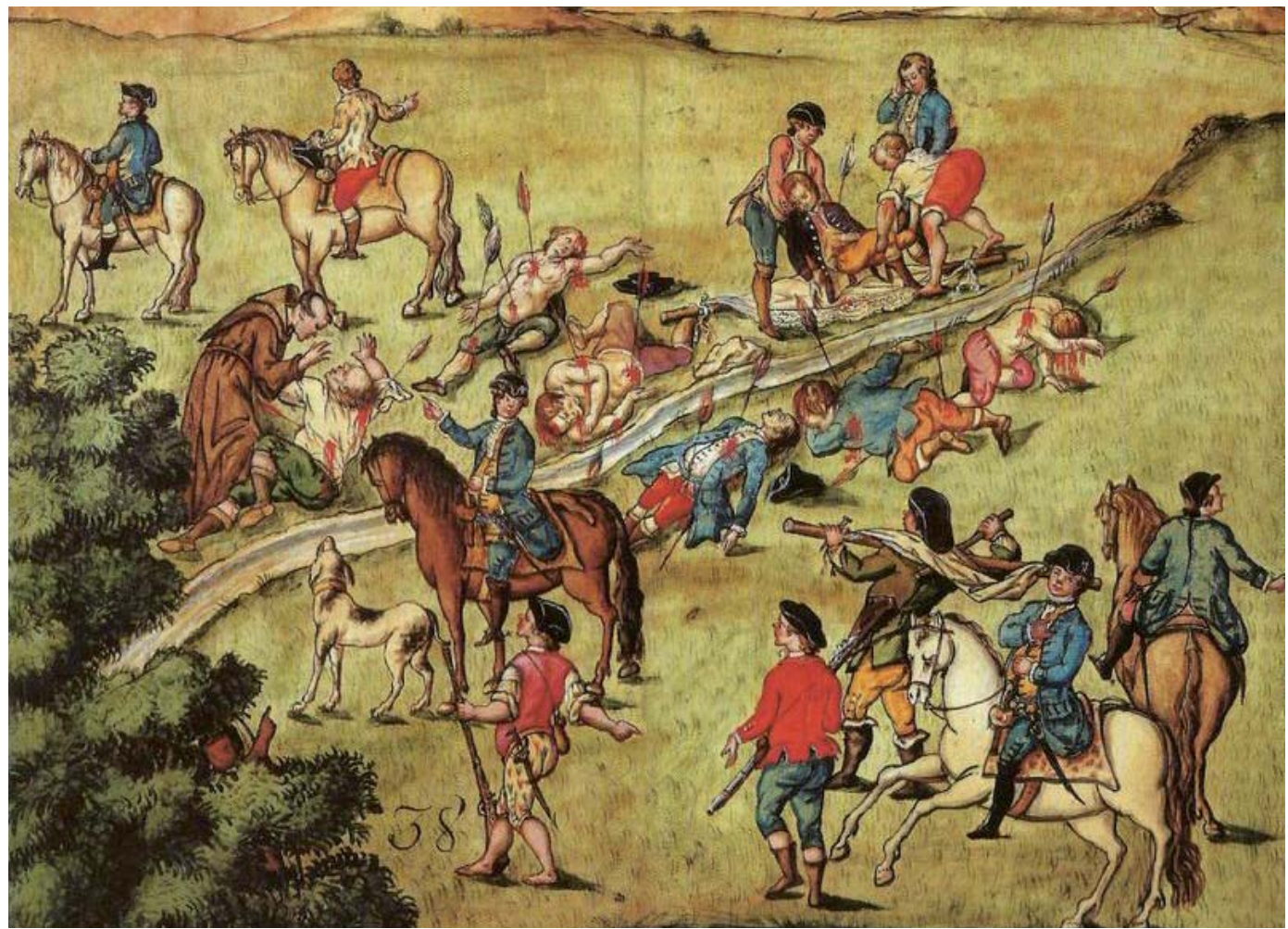

Figura 20 - Cena 38 - manda o Tenente Coronel ao Tenente Candido Xavier com huma partida de gente de cavalo procurar os Camaradas mortos, e o Padre Cappelão para confeçar hum, e mantendo-se estes nas redes, conduzirão-se ao abarracamento, para Ihes dar Sepultura; não aparecem ja Indios no Campo, e só alguns - muito ao longe que se vão metendo nos Mattos.

Fonte: Sampaio e Souza (1962).

Os corpos dos seis homens foram sepultados todos em uma cova, levantando-se uma grande cruz ao pé desta. José Pinto, que chegara ainda com vida, durou vinte e quatro horas, com uma flecha de pederneira cravada no corpo, a qual não se pôde tirar. "Confessou-se várias vêzes, e perguntado como foi a morte dos camaradas, só se intendeu dizer que os índios que pareciam mais amigos foram os peiores" (SAMPAIO E SOUZA, 1956, p. 46). Miranda dedicou uma das estampas ao enterramento dos 
homens de Botelho nos Campos de Guarapuava, mas essa imagem é a única que se extraviou do conjunto da obra.

Com essa emboscada dos indígenas, Afonso Botelho não teve outra opção a não ser retirar-se dos campos. No entanto é preciso questionar a suposta fuga pacífica da expedição de Botelho, já que os militares estavam muito bem preparados, com armas de fogo, munição e, inclusive, canhões. A retirada militar, sem vingança, é algo, pelo menos, questionável. Uma expedição militar seria vítima de um grupo indígena e não dispararia nem um tiro? Não houve reação? Não teriam matado dezenas de índios antes de deixar o acampamento? Não podemos responder a essas perguntas com base em documentos, mas a falta deles não nos impede de questionar esse fato, assim como vários outros relativos ao contato entre os militares e os Kaingang nessa expedição de conquista.

O que temos registrado no relatório de Botelho é que a expedição não teve outra opção senão deixar os campos. A resolução foi tomada em conjunto, determinando o tenente "[...] retirar toda a expedição a salvar as vidas, e o trem de Sua Majestade, que tudo pereceria sem remédio em poucos dias, pela falta de mantimentos, e as mais referidas circunstâncias" (SAMPAIO E SOUZA, 1956, p. 47). A retirada se deu no dia onze de janeiro de 1772 , sendo esse fato pintado na última estampa desenhada da narrativa imagética de Miranda. Veja-se: 


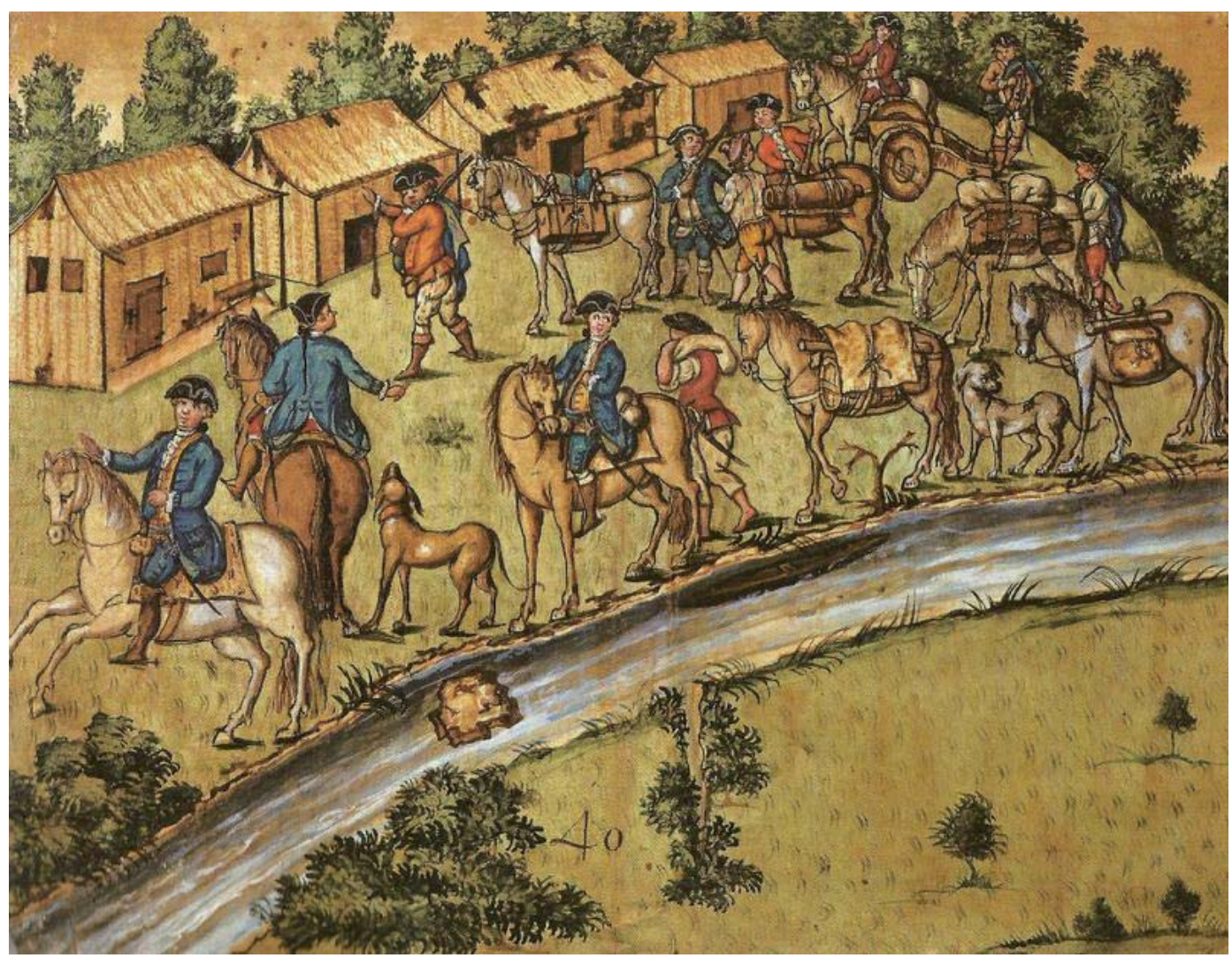

Figura 21 - Cena 40 - retirada do Campo com todo o trem.

Fonte: Sampaio e Souza (1962).

Uma vez mais, os Kaingang haviam expulsado de seu território os invasores fóg (não indígenas). Retardariam, ainda, por quase meio século, o estabelecimento núcleos populacionais na região dos Campos de Guarapuava, o que se deu apenas a partir do ano de 1810, por uma expedição militar muito bem armada.

Para a população Kaingang dos campos centrais do Paraná, as expedições de Botelho representaram um momento crucial na sua trajetória histórica, a partir do qual a invasão de seu território tradicional pelos nacionais marcaria o início de um tempo em que diversos fatores tratariam de pôr em dúvida a sobrevivência física e cultural da etnia. Sendo assim, o relato dessas estampas, que ficaram desconhecidas por cerca de duzentos anos, consiste em material de grande interesse e valor histórico para a grande epopeia do Kaingang e sua indômita resistência às hordas invasoras. 
Relatos, memórias e narrativas na construção do imaginário do povo Kaingang: as estampas de Joaquim José de Miranda na conquista dos Campos de Guarapuava

\section{REFERÊNCIAS}

AMBROSETTI, Juan Bautista. Los indios Kaingángues de San Pedro (Misiones), con un vocabulario. Revista del Jardin Zoológico de Buenos Aires, Buenos Aires, tomo II, entrada X, p. 305-87, 1895.

BALDUS, Herbert. O culto aos mortos entre os Kaingang de Palmas. In: . Ensaios de etnologia brasileira. São Paulo; Rio de Janeiro; Recife: Companhia Editora Nacional, 1937.

BELLUZO, Ana Maria de Moraes et al. Do contato ao confronto: a conquista de Guarapuava no século XVIII. São Paulo: PNP Paribas, 2003.

BELLUZZO, Ana Maria de Moraes; PICCOLI, Valéria. Desenho e conquista territorial. In: BELLUZO, Ana Maria de Moraes et al. Do contato ao confronto: a conquista de Guarapuava no século XVIII. São Paulo: BNP Paribas, 2003.

BORBA, Telêmaco Morosini. Actualidade indígena. Curitiba: Impressora Paranaense, 1908.

BURKE, Peter. Testemunha ocular: história e imagem. Tradução de Vera Maria Xavier dos Santos. Bauru, SP: EDUSC, 2004.

CARNEIRO, Newton. Iconografia paranaense. Curitiba: Impressora Paranaense, 1950.

CHAGAS LIMA, Francisco das. Memoria sobre o descobrimento e colônia de Guarapuava. Revista Trimensal de Historia e Geographia ou Jornal do Instituto Historico e Geographico Brasileiro, Rio de Janeiro, tomo IV, n. 13, p. 43-64, 1842.

CLASTRES, Pierre. Arqueologia da violência - pesquisas de antropologia política. Tradução de Paulo Neves. São Paulo: Cosac Naify, 2011.

KELLER, Franz. Noções sobre os indígenas da província do Paraná. In: LOVATO, Lêda Aparecida. A contribuição de Franz Keller à etnografia do Paraná. Boletim do Museu do Índio, Antropologia, Rio de Janeiro, n. 1, p. 3-44, 1974.

MABILDE, Pierre François Alphonse Booth. Apontamentos sobre os indígenas selvagens da Nação Coroados dos matos da Província do Rio Grande do Sul. São Paulo: IBRASA; Brasília: INL, Fundação Nacional Pró-Memória, 1983.

MANIZER, Henrich Henrikhovitch. Os Kaingang de São Paulo. Tradução de Juracilda Veiga. Campinas, SP: Curt Nimuendajú, 2006.

MOTA, Lúcio Tadeu. As guerras dos índios Kaingang: a história épica dos índios Kaingang no Paraná (1769-1924). 2. ed. Maringá, PR: Eduem, 1994.

NIMUENDAJÚ, Curt Unkel. As lendas da criação e destruição do mundo como fundamentos da religião dos Apapapocúca-Guarani. São Paulo: HUCITEC, 1987.

SAMPAIO E SOUZA, Afonso Botelho de. Anais da Biblioteca Nacional, Rio de Janeiro, v. 76, 1962. 
SEVCENKO, Nicolau. O ciclo de Miranda: utopia indigenista no Brasil pombalino. In: BELLUZO, Ana Maria de Moraes et al. Do contato ao confronto: a conquista de Guarapuava no século XVIII. São Paulo: BNP Paribas, 2003.

STOLS, Eddy. A iconografia do Brasil nos países baixos do século XVI ao século XX: uma tentativa de avaliação global. Revista USP, São Paulo, v. 30, jun./ago. 1996. Disponível em: <http://www.usp.br/revistausp/30/02-stols.pdf>. Acesso em: 25 jul. 2015.

VIEIRA, Antônio. Cartas. São Paulo: Editora Brasileira, 1970.

VIVEIROS DE CASTRO, Eduardo. O mármore e a murta: sobre a inconstância da alma selvagem. In: . A inconstância da alma selvagem e outros ensaios de antropologia. São Paulo: Cosac \& Naify, 2002. p. 256-94.

\section{Sobre o autor:}

Toni Juliano Bandeira: Graduado em Letras Português/Espanhol pela Universidade Estadual do Oeste do Paraná- Cascavel (2013) e Mestre em Letras também pela Universidade Estadual do Oeste do Paraná (2016). Atualmente é professor do Quadro Próprio do Magistério da Secretaria de Estado da Educação do Paraná, trabalhando na Terra Indígena Rio das Cobras. E-mail: tonibandiera@hotmail.com

Recebido em 17 de outubro de 2016

Aprovado para publicação em 2 de maio 2017 